\title{
More Docked Vesicles and Larger Active Zones at Basket Cell-to-Granule Cell Synapses in a Rat Model of Temporal Lobe Epilepsy
}

\author{
(-Paul S. Buckmaster, ${ }^{1,2}$ Ruth Yamawaki, ${ }^{1}$ and Khushdev Thind ${ }^{1}$ \\ Departments of ${ }^{1}$ Comparative Medicine and ${ }^{2}$ Neurology and Neurological Sciences, Stanford University, Stanford, California 94305
}

Temporal lobe epilepsy is a common and challenging clinical problem, and its pathophysiological mechanisms remain unclear. One possibility is insufficient inhibition in the hippocampal formation where seizures tend to initiate. Normally, hippocampal basket cells provide strong and reliable synaptic inhibition at principal cell somata. In a rat model of temporal lobe epilepsy, basket cell-to-granule cell $(\mathrm{BC} \rightarrow \mathrm{GC})$ synaptic transmission is more likely to fail, but the underlying cause is unknown. At some synapses, probability of release correlates with bouton size, active zone area, and number of docked vesicles. The present study tested the hypothesis that impaired GABAergic transmission at $\mathrm{BC} \rightarrow \mathrm{GC}$ synapses is attributable to ultrastructural changes. Boutons making axosomatic symmetric synapses in the granule cell layer were reconstructed from serial electron micrographs. $\mathrm{BC} \rightarrow \mathrm{GC}$ boutons were predicted to be smaller in volume, have fewer and smaller active zones, and contain fewer vesicles, including fewer docked vesicles. Results revealed the opposite. Compared with controls, epileptic pilocarpine-treated rats displayed boutons with over twice the average volume, active zone area, total vesicles, and docked vesicles and with more vesicles closer to active zones. Larger active zones in epileptic rats are consistent with previous reports of larger amplitude miniature IPSCs and larger $\mathrm{BC} \rightarrow \mathrm{GC}$ quantal size. Results of this study indicate that transmission failures at $\mathrm{BC} \rightarrow \mathrm{GC}$ synapses in epileptic pilocarpine-treated rats are not attributable to smaller boutons or fewer docked vesicles. Instead, processes following vesicle docking, including priming, $\mathrm{Ca}^{2+}$ entry, or $\mathrm{Ca}^{2+}$ coupling with exocytosis, might be responsible.

Key words: bouton; dentate gyrus; electron microscopy; GABA; inhibition; ultrastructure

\section{Significance Statement}

One in 26 people develops epilepsy, and temporal lobe epilepsy is a common form. Up to one-third of patients are resistant to currently available treatments. This study tested a potential underlying mechanism for previously reported impaired inhibition in epileptic animals at basket cell-to-granule cell $(\mathrm{BC} \rightarrow \mathrm{GC})$ synapses, which normally are reliable and strong. Electron microscopy was used to evaluate $3 \mathrm{D}$ ultrastructure of $\mathrm{BC} \rightarrow \mathrm{GC}$ synapses in a rat model of temporal lobe epilepsy. The hypothesis was that impaired synaptic transmission is attributable to smaller boutons, smaller synapses, and abnormally low numbers of synaptic vesicles. Results revealed the opposite. These findings suggest that impaired transmission at $\mathrm{BC} \rightarrow \mathrm{GC}$ synapses in epileptic rats is attributable to later steps in exocytosis following vesicle docking.

\section{Introduction}

One in 26 people develops epilepsy (Hesdorffer et al., 2011), and anti-seizure drugs fail in $23 \%$ of cases (Picot et al., 2008) or more (Kwan and Brodie, 2000). Resection of the seizure-generating focus can be a treatment option, and $50 \%-73 \%$ of patients re-

Received Nov. 10, 2015; revised Jan. 20, 2016; accepted Feb. 4, 2016.

Author contributions: P.S.B. designed research; P.S.B., R.Y., and K.T. performed research; P.S.B. analyzed data; P.S.B. wrote the paper.

This work was supported by National Institutes of Health/National Institute of Neurological Disorders and Stroke. The authors declare no competing financial interests.

Correspondence should be addressed to Dr. Paul S. Buckmaster, 300 Pasteur Drive, R321 Edwards Building, Department of Comparative Medicine, Stanford University, Stanford, CA 94305. E-mail: psb@stanford.edu.

DOI:10.1523/JNEUROSCI.4049-15.2016

Copyright $\odot 2016$ the authors $\quad 0270-6474 / 16 / 363295-14 \$ 15.00 / 0$ ferred to surgical centers have temporal lobe epilepsy (TéllezZenteno and Hernández-Ronquillo, 2012). Depth electrodes sometimes are implanted to localize sites of seizure onset. Results from those evaluations suggest that, in patients with temporal lobe epilepsy, seizures usually start in the hippocampus (Quesney, 1986; Spencer et al., 1987; Sperling and O'Connor, 1989; Spanedda et al., 1997). The dentate gyrus has been suspected to play a role in seizure initiation in part because it is hyperexcitable (Gabriel et al., 2004) and granule cells are less inhibited than in controls (Williamson et al., 1995, 1999) after temporal lobe epilepsy had developed. Animal models of temporal lobe epilepsy display similar abnormalities (Nadler et al., 1978; Cronin et al., 1992). Reduced inhibition of granule cells might be an epileptogenic mechanism. 
In animal models of temporal lobe epilepsy, granule cells display aberrantly low frequencies of miniature IPSCs (Kobayashi and Buckmaster, 2003; Shao and Dudek, 2005; Sun et al., 2007). Most miniature IPSCs recorded in granule cells are generated by somatic GABAergic synapses (Soltesz et al., 1995). Basket cells are the major source of inhibitory synaptic input to granule cell somata (Kraushaar and Jonas, 2000). Reduced miniature IPSC frequency in epileptic subjects could be attributable to lower release probability and/or fewer basket cell-to-granule cell $(\mathrm{BC} \rightarrow \mathrm{GC})$ synapses. However, basket cells are relatively resistant to epileptogenic injuries compared with some other interneurons (Buckmaster and Dudek, 1997; Sun et al., 2007), and numbers of inhibitory synapses with granule cell somata are not significantly reduced in patients with temporal lobe epilepsy (Wittner et al., 2001) or in epileptic pilocarpine-treated rats (Thind et al., 2010). Together, these findings suggest that reduced inhibition of granule cells in temporal lobe epilepsy might be attributable, at least in part, to dysfunction of surviving $\mathrm{BC} \rightarrow \mathrm{GC}$ synapses.

Recordings of unitary IPSCs in monosynaptically coupled neurons reveal that $\mathrm{BC} \rightarrow \mathrm{GC}$ synaptic transmission is impaired in rats that develop permanent epilepsy after surviving acute status epilepticus induced by systemic treatment with pilocarpine (Zhang and Buckmaster, 2009). Epileptic pilocarpine-treated rats display anatomical and electrophysiological abnormalities in the dentate gyrus similar to patients with temporal lobe epilepsy (Kobayashi and Buckmaster, 2003) and their spontaneous seizures usually initiate in the hippocampal formation (Toyoda et al., 2013). BC $\rightarrow$ GC synapses in epileptic rats have higher failure rates than in controls, which does not appear to be attributable to abnormally high levels of presynaptic inhibition. Instead, granule cell responses to high-frequency trains of basket cell action potentials reveal smaller readily releasable pools of synaptic vesicles in epileptic rats. In some circuits, including excitatory hippocampal synapses, readily releasable pool size corresponds with the number of docked vesicles (Schikorski and Stevens, 2001). Therefore, we hypothesized that $\mathrm{BC} \rightarrow \mathrm{GC}$ synaptic boutons would contain fewer docked vesicles in epileptic pilocarpinetreated rats.

The ultrastructural size principle contends that synaptic efficacy is directly related to synaptic bouton size, which correlates positively with other ultrastructural features, including active zone area and number of synaptic vesicles (Pierce and Lewin, 1994). If this principle, which is based primarily on data from excitatory synapses, also pertains to inhibitory synapses, then $\mathrm{BC} \rightarrow \mathrm{GC}$ boutons in animal models of temporal lobe epilepsy might be smaller, have smaller active zones, and have fewer synaptic vesicles than controls. To test these predictions, the present study compared ultrastructural features of $\mathrm{BC} \rightarrow \mathrm{GC}$ synaptic boutons in control and epileptic pilocarpine-treated rats. In epileptic pilocarpine- and kainate-treated rats, CA1 pyramidal cells have reduced miniature IPSC frequency that correlates with lower densities of synaptic vesicles in GABAergic axosomatic boutons (Hirsch et al., 1999). To our knowledge, no previous study has evaluated vesicles of $\mathrm{BC} \rightarrow \mathrm{GC}$ synapses of the dentate gyrus in temporal lobe epilepsy.

\section{Materials and Methods}

All animal procedures were conducted in accordance with the National Institutes of Health Guide for the Care and Use of Laboratory Animals and approved by an institutional animal care and use committee at Stanford University. Male Sprague Dawley rats (Harlan Laboratories) at $34-37 \mathrm{~d}$ of age were treated with pilocarpine. Pilocarpine hydrochloride $(380 \mathrm{mg} / \mathrm{kg}$, i.p.) was administered $20 \mathrm{~min}$ after atropine methyl bromide
(5 mg/kg, i.p.). Diazepam (10 mg/kg, i.p.) was administered $2 \mathrm{~h}$ after the onset of motor seizures and was repeated as needed for the next $10 \mathrm{~h}$ to suppress convulsions. To reduce the number of animals used, four rats that had been treated identically with pilocarpine but did not develop status epilepticus were included in the control group. Two more naive control rats were added, so control and epileptic groups would both consist of six animals. Results from both types of controls were combined. Naive and pilocarpine-treated control animals are indicated by different markers in all plots. Previous studies that included larger samples of naive and pilocarpine-treated control rats found no significant differences in electrophysiological and anatomical parameters of interneurons and GABAergic synapses in the dentate gyrus or other brain regions (Kobayashi and Buckmaster, 2003; Kobayashi et al., 2003; Kumar and Buckmaster, 2006), but those studies did not evaluate ultrastructure. All rats that experienced status epilepticus, but none of the controls was observed by chance to have at least one spontaneous motor seizure (grade 3 or greater) (Racine, 1972) at least $14 \mathrm{~d}$ after pilocarpine treatment. However, rats were not systematically monitored for spontaneous seizures. Therefore, the total number and timing of seizures experienced were not known and might be a confounding effect on GABAergic synaptic ultrastructure.

Rats were killed by barbiturate overdose ( $>100 \mathrm{mg} / \mathrm{kg}$ pentobarbital, i.p.) when they were 3-9 months old (average 5 and 6 months old in epileptic and control rats, respectively) and perfused through the ascending aorta at $30 \mathrm{ml} / \mathrm{min}$ for $1 \mathrm{~min}$ with $0.9 \%$ sodium chloride and $30 \mathrm{~min}$ with $2 \%$ formaldehyde and $2 \%$ glutaraldehyde in $0.1 \mathrm{~m}$ phosphate buffer, $\mathrm{pH} 7.4$, at $4^{\circ} \mathrm{C}$. Brains postfixed overnight at $4^{\circ} \mathrm{C}$. A vibratome was used to make $80-\mu \mathrm{m}$-thick horizontal sections. Sections from -5.1 to -7.1 mm below bregma (Paxinos and Watson, 1998) were trimmed to isolate regions of the dentate gyrus.

Dentate gyrus tissue was postfixed with potassium ferricyanidereduced $2 \% \mathrm{OsO}_{4}$ in $0.1 \mathrm{M}$ sodium cacodylate buffer, $\mathrm{pH} 7.2$, for $2 \mathrm{~h}$, rinsed in the same buffer, and then rinsed in distilled water before being placed in $2 \%$ aqueous uranyl acetate overnight on a rotator. After rinses in distilled water, sections were placed in $0.6 \%$ lead nitrate in $0.4 \%$ $\mathrm{L}$-aspartate for $2 \mathrm{~h}$ at $60^{\circ} \mathrm{C}$, rinsed in distilled water, dehydrated in a series of ethanols, placed in propylene oxide, and then embedded in Epon and propylene oxide mix (1:1 and 3:1) before being gradually transferred to pure Araldite/Eponate-12 (Ted Pella) and embedded in BEEM capsules at $60^{\circ} \mathrm{C}$ for $24 \mathrm{~h}$. Block faces were trimmed, and an ultramicrotome (Reichert Ultracut S, Leica) was used to make ultrathin sections of silver interference color, estimated to be $35 \mathrm{~nm}$ thick. Serial sections were collected on coated, nickel single-slot grids. Sections were poststained with Sato's lead stain for 1-3 s.

A transmission electron microscope (JEOL 100CX) at 36,000 $\times$ magnification was used to identify axosomatic symmetric synapses in the granule cell layer that were identified by parallel membranes, cleft material, concentration of presynaptic vesicles, and a thin postsynaptic density (Gray, 1959). Somata were identified as putative granule cells based on their location in the granule cell layer, small size, round shape, and thin cytoplasm. Boutons were chosen for reconstruction by investigators who were blind to experimental groups. Boutons were selected for reconstruction if they fulfilled the following criteria: (1) they made a symmetric synapse with a putative granule cell somata; (2) the synapse was perpendicular to the plane of section; and (3) the bouton could be followed completely across serial sections. Selected boutons were photographed in their entirety across serial sections. Serial electron micrographs were printed at a final magnification of $92,000 \times$. In some cases, a bouton profile extended beyond the field of view and multiple electron micrographs were made so that montages of prints could be assembled to include the entire bouton profile. A total of 5123 electron micrographs were made. Only 42 sections were missing, which was $<1 \%$ in both control and epileptic groups.

Synaptic boutons were three-dimensionally reconstructed from serial electron micrographs using Neurolucida software (MBF Bioscience) and an interactive pen display monitor (Cintiq, Wacom). Contours were made to outline synaptic boutons, mitochondria, interfaces (direct appositions of presynaptic and postsynaptic membranes), and active zones (presynaptic border of the synaptic cleft). Different colors designated 


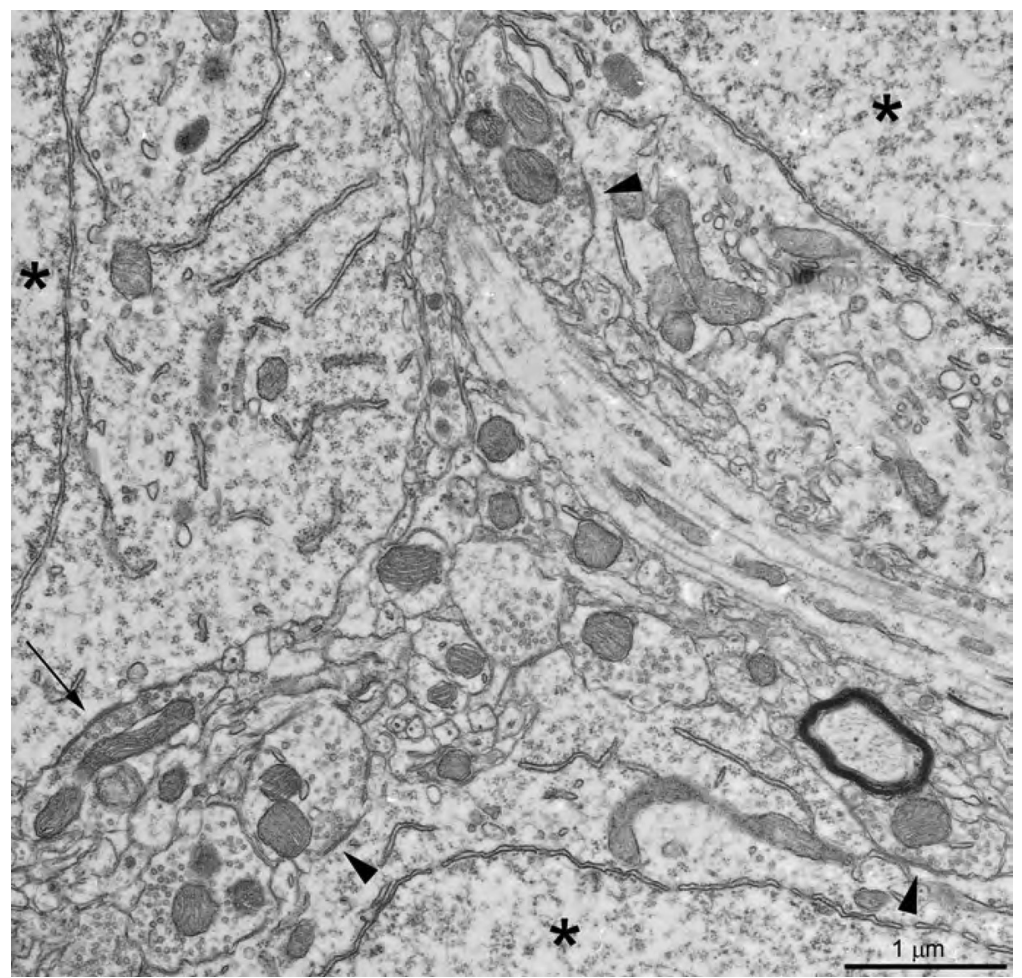

Figure 1. Axosomatic symmetric synapses in the granule cell layer of an epileptic pilocarpine-treated rat. Intersection of three granule cells (nuclei indicated by asterisks) with several boutons evident that make axosomatic symmetric synapses (arrowheads) One bouton was reconstructed from serial electron micrographs (arrow).

different mitochondria or different interfaces of individual boutons. Markers were used to designate clear synaptic vesicles, including docked vesicles, which were identified by their direct contact with an active zone. It is possible that vesicles cut at section surfaces might have been counted twice in serial sections, resulting in an overestimation of vesicle number, but relative values of control and experimental groups were not likely to be affected. Reconstructed boutons included both en passant and terminal types. Contours outlining bouton borders extended across narrow points of axon connection. If a mitochondrion projected from a bouton partially into a narrow segment of the axon, the bouton reconstruction included that part of the axon to avoid excluding part of an intact mitochondrion.

To reduce confounding effects of variation from sources other than experimental group differences, the following steps were taken. All rats were handled, treated, and perfused, and 80 - $\mu$ m-thick sections were generated by one investigator. Generation of ultrathin sections and electron micrographs was divided equally between two investigators who each acquired data for five synaptic boutons from every animal. Investigators were blind to experimental groups during data acquisition and analysis.

Measured parameters of 10 boutons from each animal were averaged before calculating control and epileptic group averages. For all statistical comparisons between control and epileptic groups, sample sizes consisted of the number of animals in each group (6). In most cases, a two-tailed $t$ test was used to test for differences between control and epileptic groups, which assumes that samples were drawn from normally distributed populations with the same variances (SigmaPlot 12, Systat). The Shapiro-Wilk test was used to measure normality. Equal variance was tested by checking the variability about the group means. If normality or equal variance tests failed, a Mann-Whitney rank sum test was used. Differences were considered significant if $p<0.05$. The power of a $t$ test is the probability that the test will detect a difference between the groups if there really is a difference. Power was calculated using SigmaPlot, which follows the method described by Zar (1984). Results are reported as mean \pm SEM.

\section{Results}

In the granule cell layer of control and epileptic pilocarpine-treated rats, numerous boutons were evident that made symmetric axosomatic synapses with round cells containing a thin shell of cytoplasm surrounding a nucleus (Fig. 1). Synaptic clefts, bordered by parallel presynaptic and postsynaptic membranes, were $\sim 12$ $\mathrm{nm}$ wide and contained amorphous, dense material (Fig. 2C,F). Clear vesicles accumulated close to active zones where amorphous material extended into the cytoplasm. Puncta adherentia were sometimes evident between presynaptic and postsynaptic membranes and were distinguished from symmetrical synapses in part by a lack of associated vesicles. Large dense-core vesicles were sometimes evident, but smaller, clear, pleomorphic vesicles predominated. Only clear vesicles were included for analysis.

A total of 120 synaptic boutons that made symmetric axosomatic synapses with granule cells were reconstructed from serial electron micrographs (Fig. 2). Boutons extended across $37 \pm 2$ (mean \pm SEM) and $45 \pm 3$ sections in control and epileptic rats, respectively $(p=0.045, t$ test, power $=0.54)$. Reconstructions included enclosed contours of the bouton membrane and mitochondria; markers depicting clear synaptic vesicles, including those that touched an active zone and were designated as docked; and open contours of active zones and direct appositions of presynaptic and postsynaptic membranes referred to as "interfaces" (Peters and Harriman, 1990). Ten boutons were reconstructed for each animal (Fig. 3). Previous studies report considerable variability in the size and shape of hippocampal boutons and synapses (Harris and Sultan, 1995; Schikorski and Stevens, 1997), including GABAergic synapses (Biró et al., 2006). Similarly, in the present study, boutons making axosomatic symmetric synapses with granule cells were variable even in individual animals.

To test for scaling relationships between the size of synaptic boutons and other ultrastructural features, bouton volume was plotted against mitochondrial volume, interface area, number and area of active zones, number of clear vesicles, and number of docked vesicles (Fig. 4A-F). All parameters correlated with bouton volume $(p<0.001$, ANOVA, power $=1.0)$. In addition, interface area correlated with active zone area (Fig. $4 G$ ), active zone area correlated with the number of docked vesicles (Fig. $4 H$ ), and the total number of vesicles correlated with the number of docked vesicles (Fig. $4 I)($ all $p<0.001$, ANOVA, power $=1.0)$. These findings revealed scaling relationships between many ultrastructural features of boutons and synapses.

As explained in the Introduction, based on the ultrastructural size principle and previously reported measures of inhibitory synaptic function in granule cells, $\mathrm{BC} \rightarrow \mathrm{GC}$ boutons were predicted to be smaller in epileptic animals. However, results revealed the opposite (Fig. 5). Average bouton volume was twice as large in epileptic rats $\left(0.690 \pm 0.065 \mu \mathrm{m}^{3}\right)$ compared with controls $\left(0.333 \pm 0.024 \mu \mathrm{m}^{3}, p<0.001, t\right.$ test, power $\left.=1.0\right)($ Fig. $5 I)$. 
A

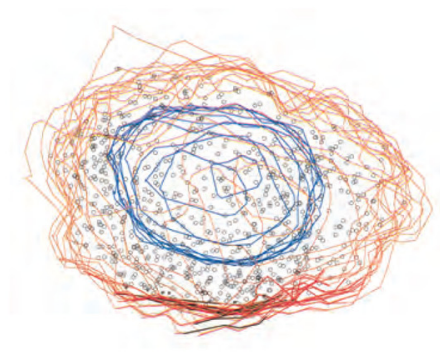

B

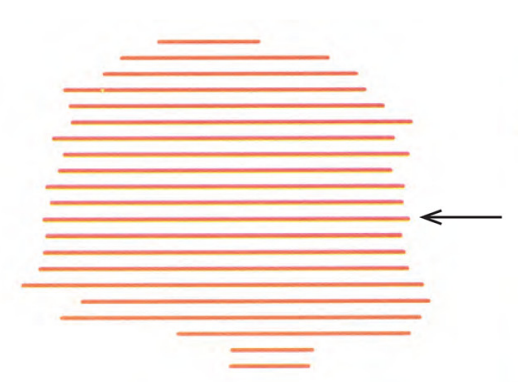

D
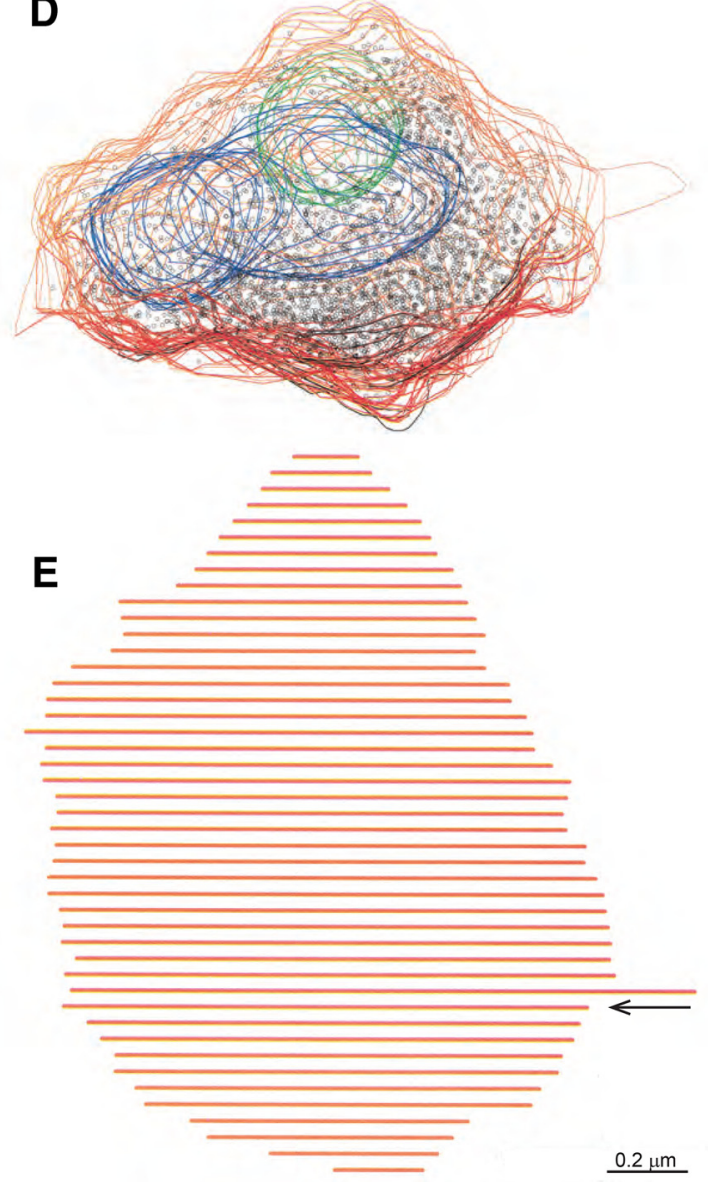

$\underline{0.2 \mu \mathrm{m}}$
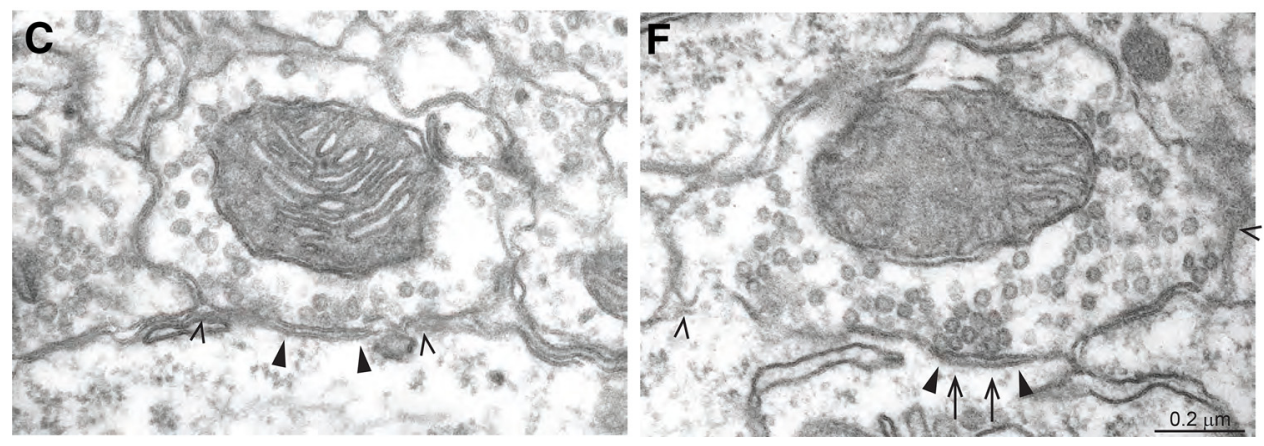

Figure 2. Reconstructed axosomatic synaptic boutons in the granule cell layer of a control $(\boldsymbol{A}-\boldsymbol{C})$ and epileptic pilocarpine-treated rat $(\boldsymbol{D}-\boldsymbol{F}) . \boldsymbol{A}, \boldsymbol{D}$, Side views. $\boldsymbol{B}, \boldsymbol{E}$, Top views. Orange represents bouton. Blue and green represent mitochondria (different colors represent different mitochondria). Red represents interface area of presynaptic and postsynaptic membrane apposition. Black represents active zones. Black markers represent clear vesicles. $\boldsymbol{C}, \boldsymbol{F}$, Electron micrographs of one section from reconstructed synapses. Corresponding sections indicated by horizontal arrow in $\boldsymbol{B}$ and E. F, Vertical arrows represent clearly docked vesicles. Filled arrowheads represent borders of active zones. Open arrowheads represent interface areas on the postsynaptic side.

These findings suggested that impaired $\mathrm{BC} \rightarrow \mathrm{GC}$ synaptic transmission was not attributable to small, atrophic boutons.

There are reports of ultrastructural damage to mitochondria in the hippocampus of patients with temporal lobe epilepsy (Kunz et al., 2000) and in epileptic pilocarpine-treated rats (Gao et al., 2007), and some evidence suggests that deficient mitochondria can contribute to synaptic dysfunction (Verstreken et al., 2005). To test that possibility, mitochondria in synaptic boutons were evaluated (Fig. 5). Only 1 of 120 sampled boutons lacked a mitochondrion. The average number of mitochondria per bouton was $1.7 \times$ higher in epileptic rats $(2.25 \pm 0.26)$ compared with controls $(1.32 \pm 0.10, p=0.009$, Mann-Whitney rank sum test) (Fig. 5J). Similarly, the total mitochondrial volume per bouton was $1.8 \times$ higher in epileptic rats $\left(0.124 \pm 0.013 \mu \mathrm{m}^{3}\right)$ compared with controls $\left(0.070 \pm 0.006 \mu \mathrm{m}^{3}, p=0.003, t\right.$ test, power $=$ 0.93 ) (Fig. $5 \mathrm{~K}$ ). However, the average volume of individual mitochrondria was similar in epileptic rats $\left(0.057 \pm 0.005 \mu \mathrm{m}^{3}\right)$ and controls ( $0.055 \pm 0.005 \mu \mathrm{m}^{3}$, Mann-Whitney rank sum test) (Fig. $5 L$ ). These values are within the range reported previously for mitochondria in hippocampal synaptic boutons (Eyre et al., 2007). Mitochondrial volume as a percentage of bouton volume in epileptic rats $(18.1 \pm 0.8 \%)$ was $85 \%$ that of controls $(21.2 \pm 1.1 \%, p=0.048, t$ test, power $=0.53)($ Fig. $5 M)$. These findings revealed more numerous mitochondria but not quite proportional total mitochondrial volume in enlarged boutons of epileptic rats. 

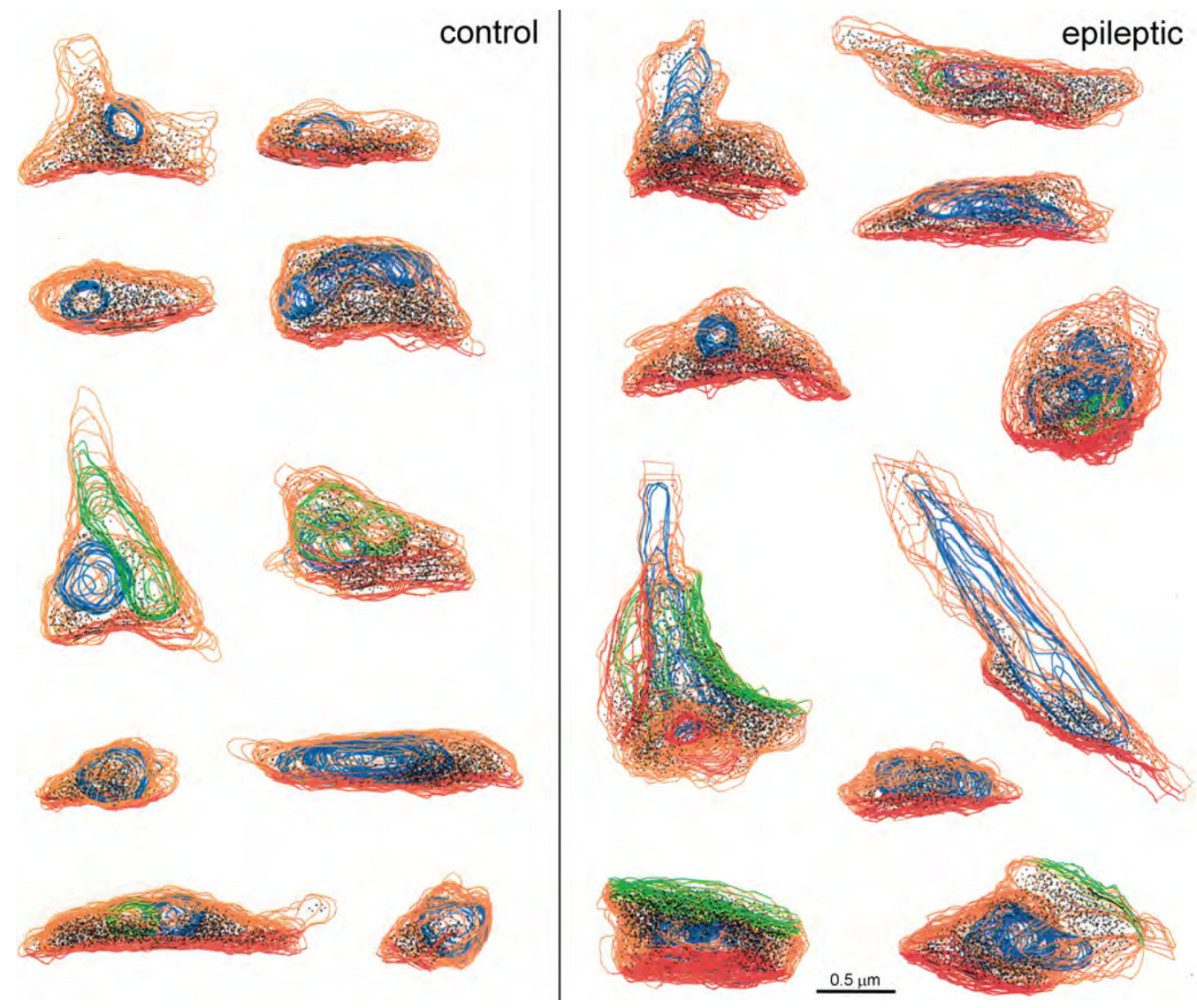

Figure 3. Reconstructed axosomatic synaptic boutons from the granule cell layer of a control and epileptic pilocarpine-treated rat. Ten boutons were reconstructed for each animal. Orange represents bouton. Blue, green, and magenta represent mitochondria (different colors represent different mitochondria). Red and green represent interface areas of presynaptic and postsynaptic membranes. Black markers represent synaptic vesicles.

Despite larger $\mathrm{BC} \rightarrow \mathrm{GC}$ boutons, synapses might be smaller in epileptic rats to explain their reduced transmission rate. Synapses were evaluated by measuring active zone and interface areas (Figs. 6, 7). Interfaces are appositions of the presynaptic bouton and membranes of the postsynaptic cell. All boutons in the sample were selected for reconstruction based on their making at least one synapse with a granule cell soma. Most boutons (79\%, 95 of $120)$ synapsed with only one granule cell, but some synapsed with two $(21 \%, 25$ of 120$)$. The average number of interfaces per bouton was identical in epileptic rats $(1.22 \pm 0.05)$ and controls $(1.22 \pm 0.05, p=1.0, t$ test, power $=0.50)($ Fig. $8 A)$, but the area per interface in epileptic rats $\left(1.11 \pm 0.10 \mu \mathrm{m}^{2}\right)$ was $1.4 \times$ that of controls $\left(0.79 \pm 0.08 \mu \mathrm{m}^{2}, p=0.016\right.$, power $\left.=0.62\right)($ Fig. $8 B)$.

Each interface included one or more active zones. Active zones are synaptic complexes consisting of parallel membranes, amorphous dense material in the cleft, and a dense accumulation of vesicles presynaptically. The proportion of active zone targets was $95.4 \%$ granule cell somata ( 231 of 242 ), $2.5 \%$ dendritic spines (6 of 242), and $2.1 \%$ dendritic shafts (5 of 242). Previous studies found that, in contrast to excitatory asymmetric synapses where a large fraction of the interface area is active zone, at symmetric synapses a smaller proportion of interface area is active zone, and active zones can be divided into multiple, irregularly shaped areas (Peters and Harriman, 1990). As explained in the Introduction, some previous studies suggest that active zones are smaller at less reliable synapses, so $\mathrm{BC} \rightarrow \mathrm{GC}$ synapses were hypothesized to have smaller active zones in epileptic rats. Results showed quite the opposite (Figs. 6, 7). The number of active zones per bouton was $1.4 \times$ higher in epileptic rats $(2.35 \pm 0.08)$ compared with controls $(1.73 \pm 0.16, p=0.015$, Mann-Whitney rank sum test) (Fig. $8 C$ ). Area per active zone was $1.7 \times$ larger in epileptic rats $\left(0.123 \pm 0.016 \mu \mathrm{m}^{2}\right)$ compared with controls $\left(0.073 \pm 0.003 \mu \mathrm{m}^{2}, p=0.002\right.$, Mann-Whitney rank sum test $)$ (Fig. $8 D$ ). In control animals, active zones occupied $14.9 \pm 1.4 \%$ of the interface area (Fig. $8 E$ ), similar to symmetric synapses with pyramidal cell somata in visual cortex (Peters et al., 1990). In epileptic rats, active zone area as a proportion of interface area was $1.3 \times$ larger than in controls $(20.0 \pm 1.5 \%, p=0.036, t$ test, power $=0.59)$. Total active zone area per bouton was $2.1 \times$ larger in epileptic rats $\left(0.240 \pm 0.029 \mu \mathrm{m}^{2}\right)$ compared with controls $\left(0.115 \pm 0.009 \mu \mathrm{m}^{2}, p=0.002\right.$, Mann-Whitney rank sum test $)$ (Fig. $8 F$ ). These findings revealed that active zone area was larger, not smaller, at $\mathrm{BC} \rightarrow \mathrm{GC}$ synapses in epileptic rats.

Some evidence suggests that efficacy of synaptic transmission is reduced at boutons with fewer synaptic vesicles (Pierce and Lewin, 1994; Hirsch et al., 1999; Li and Schwarz, 1999), so $\mathrm{BC} \rightarrow \mathrm{GC}$ boutons were hypothesized to contain fewer synaptic vesicles in epileptic rats. Results revealed the opposite. The number of vesicles per bouton was $2.4 \times$ higher in epileptic rats $(2060 \pm 190)$ compared with controls $(850 \pm 40, p<0.001$, $t$ test, power $=1.0)($ Fig. $8 G)$. The number of vesicles per interface was $2.4 \times$ higher in epileptic rats $(1760 \pm 190)$ compared with controls $(740 \pm 40, p<0.001, t$ test, power $=1.0)($ Fig. $8 H)$. The number of vesicles per active zone was $1.9 \times$ higher in epileptic rats $(1040 \pm 110)$ compared with controls $(550 \pm 50, p=0.002$, $t$ test, power $=0.96)($ Fig. $8 I)$. However, the density of vesicles in 
A

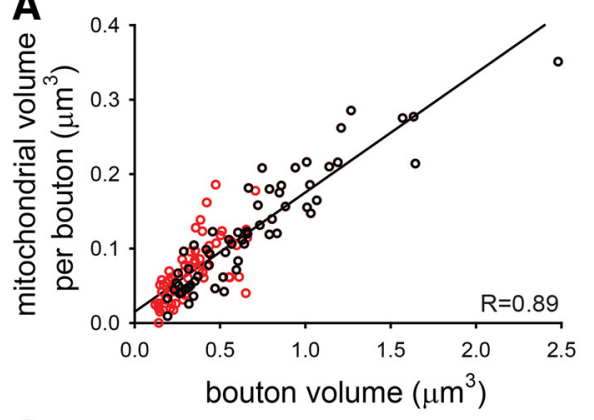

C
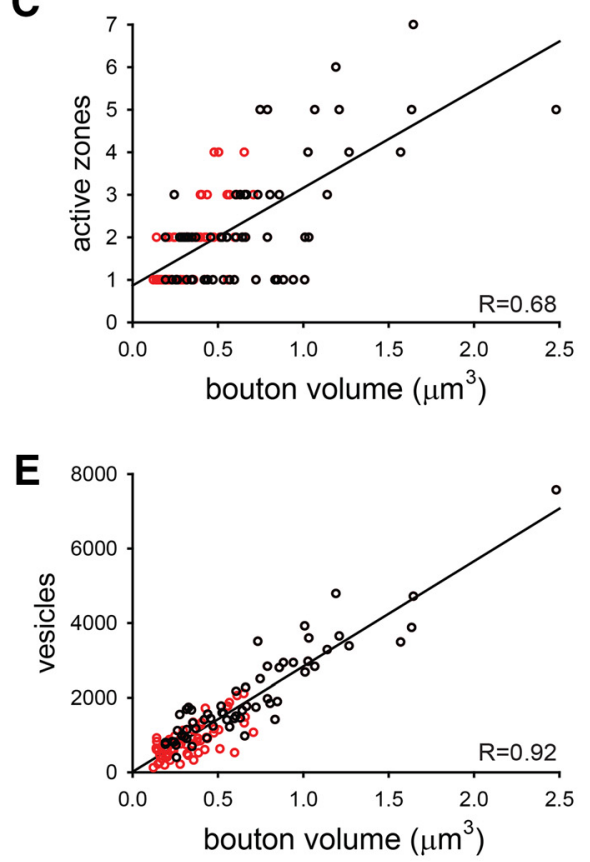

G
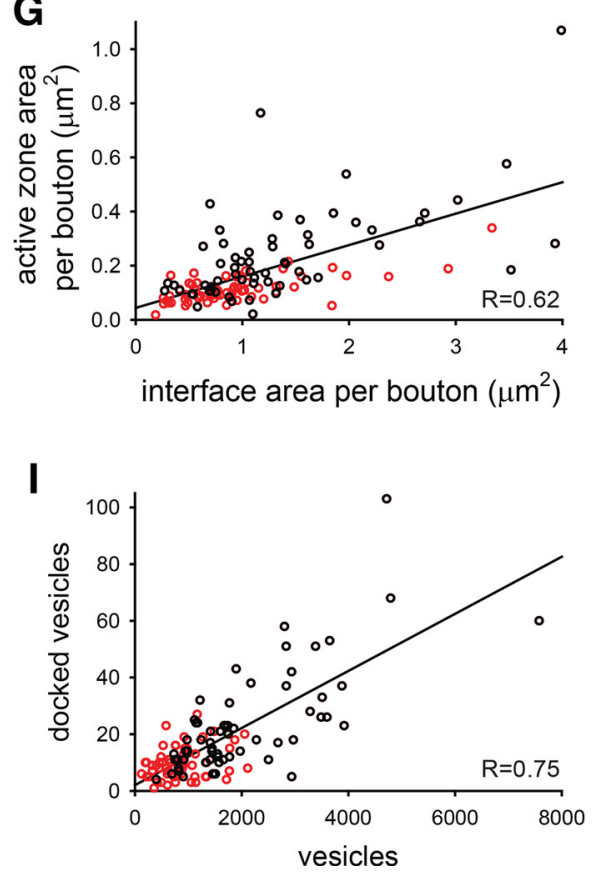

B

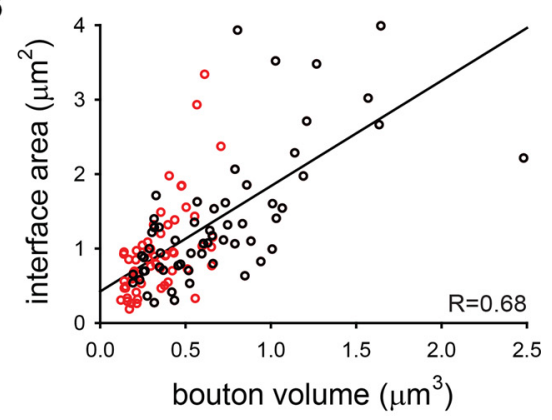

D

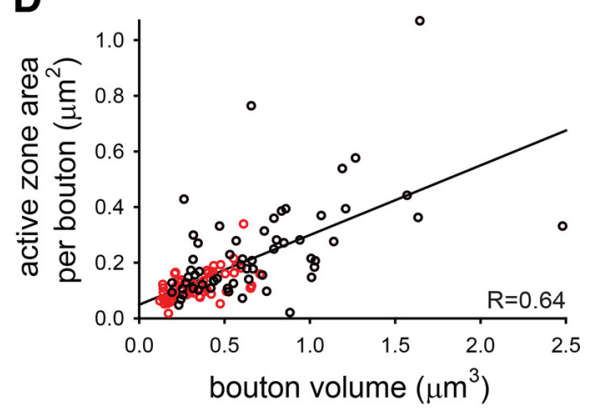

$\mathbf{F}$

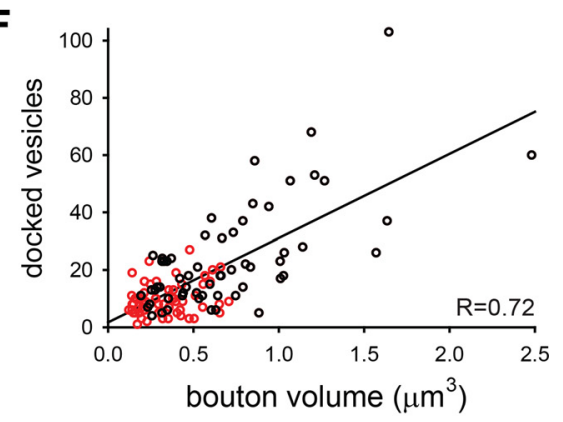

$\mathrm{H}$

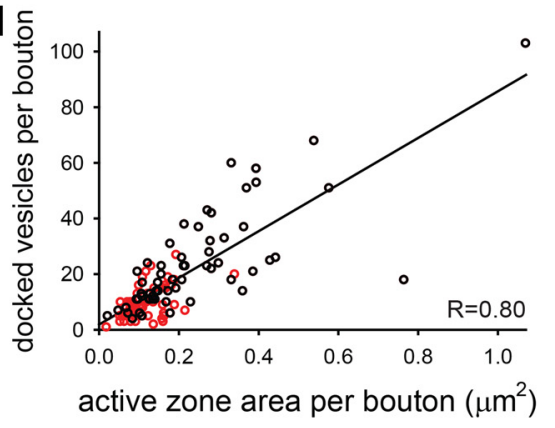

- control

- epileptic

Figure 4. Linear regression revealed correlation of ultrastructural parameters of 120 boutons forming symmetric axosomatic synapses with granule cells in control (red circles) and epileptic pilocarpine-treated rats (black circles). Bouton volume correlated with mitochondrial volume $(\boldsymbol{A})$, interface area $(\boldsymbol{B})$, number of active zones $(\boldsymbol{C})$, active zone area $(\boldsymbol{D})$, number of clear vesicles $(\boldsymbol{E})$, and number of docked vesicles $(\boldsymbol{F}) . \mathbf{G}$, Interface area correlated with active zone area. $\boldsymbol{H}$, Active zone area correlated with number of docked vesicles. $\boldsymbol{I}$, Number of vesicles correlated with number of docked vesicles. In all cases, $p<0.001$ (ANOVA). R values are indicated. 

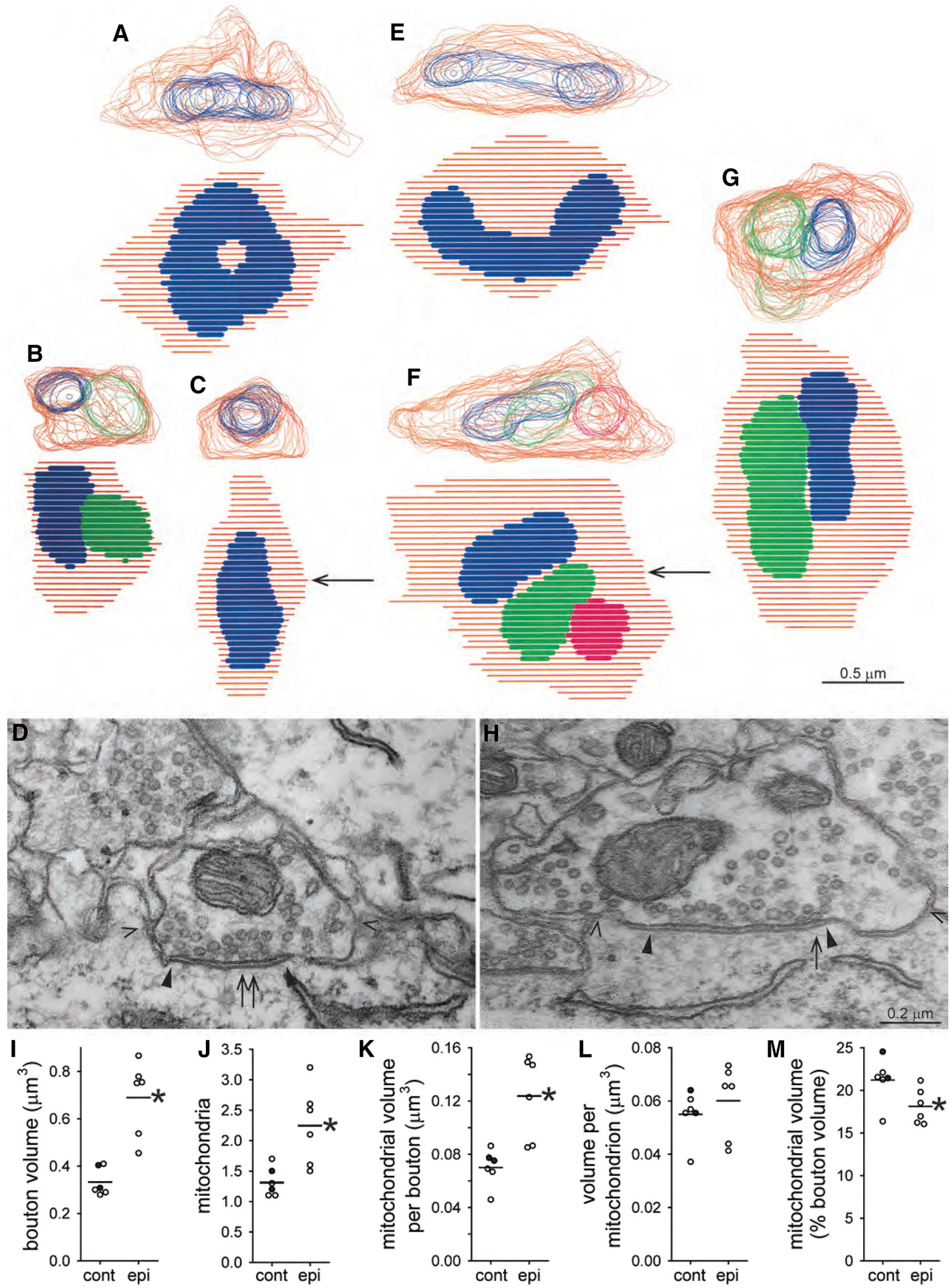

Figure 5. Axosomatic boutons in the granule cell layer are larger and contain more mitochondria in epileptic pilocarpine-treated rats. Reconstructed boutons (orange) and mitochondria (blue, green, and magenta) in control $(\boldsymbol{A}-\boldsymbol{D})$ and epileptic pilocarpine-treated rats $(\boldsymbol{E}-\boldsymbol{H})$. Side (above) and top (below) views are shown in $\boldsymbol{A}-\boldsymbol{C}$ and $\boldsymbol{E}, \boldsymbol{F}$, respectively. $\boldsymbol{D}, \boldsymbol{H}$, (Figure legend continues.) 

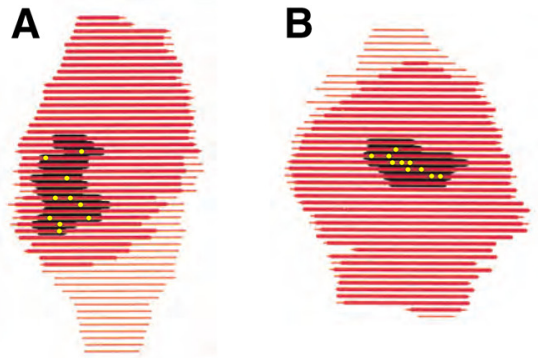

D

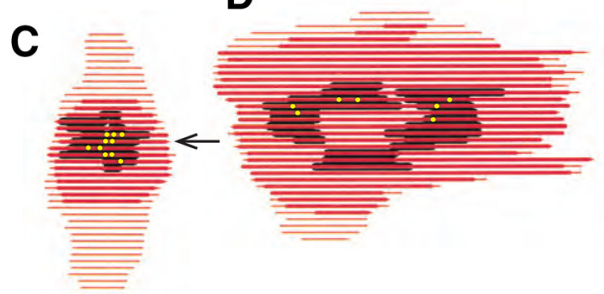

H
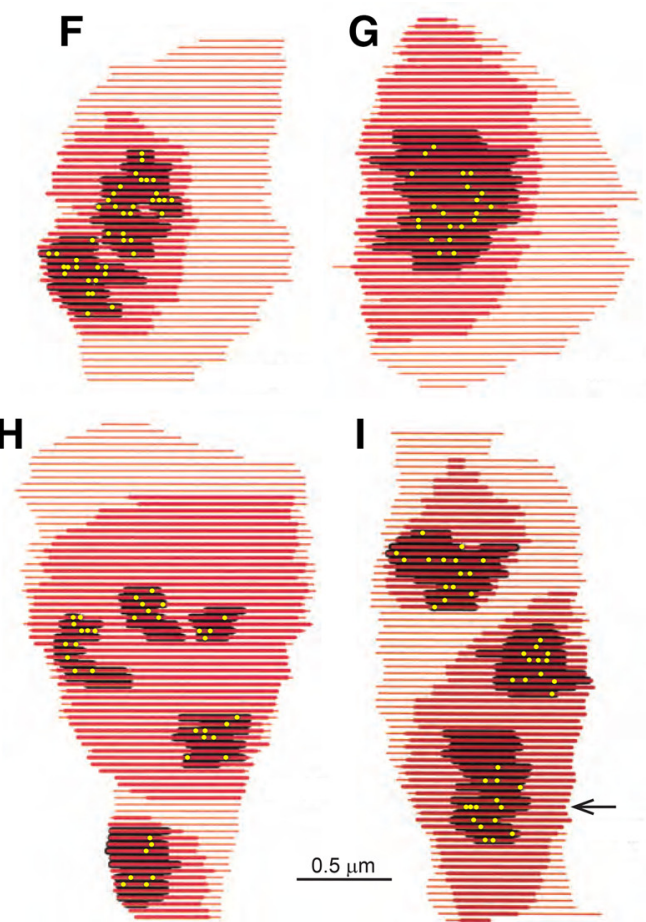

I
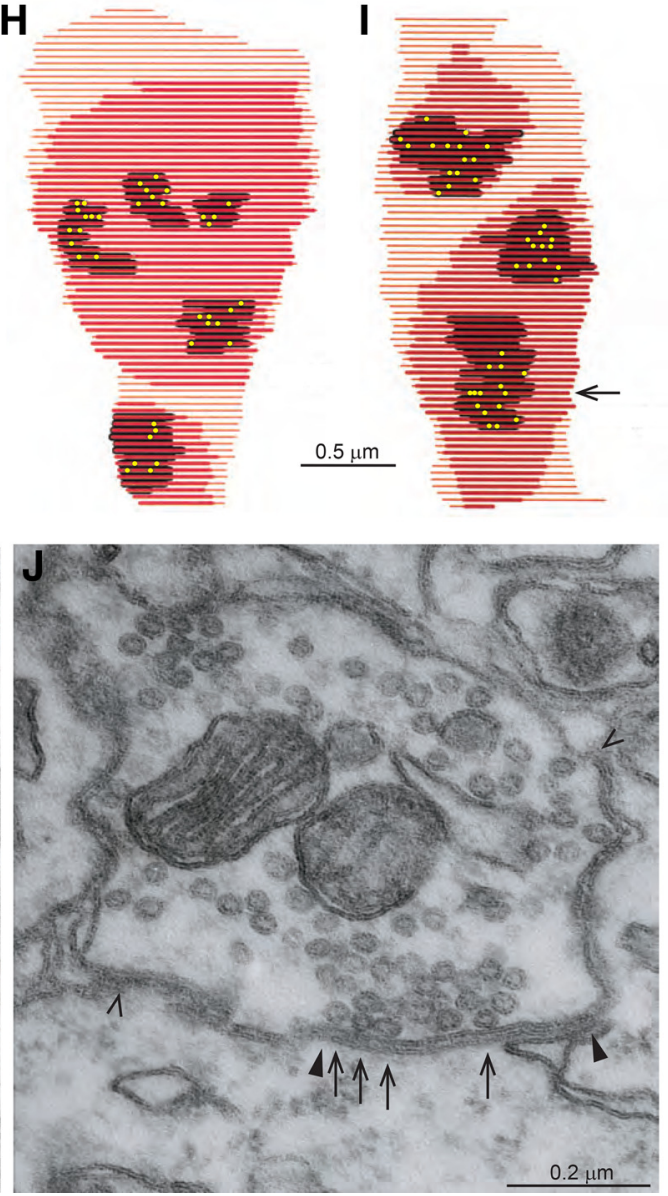

Figure 6. Surface views of single axosomatic synapses in control $(\boldsymbol{A}-\boldsymbol{E})$ and epileptic pilocarpine-treated rats $(\boldsymbol{F}-\boldsymbol{J})$. Contours of synaptic boutons (orange), interface areas of presynaptic and postsynaptic membrane appositions (red), and active zones (black) are indicated. Yellow circles represent docked vesicles. $E$, $J$, Electron micrographs of corresponding sections in reconstructions indicated by horizontal arrows in $\boldsymbol{C}$ and $\boldsymbol{I}$. Vertical arrows represent docked vesicles in micrographs. Filled arrowheads represent borders of active zones on the postsynaptic side. Open arrowheads represent interface areas on the postsynaptic side. $J$, The left border of the interface is unclear in the section shown but was verified in adjacent sections.

boutons (excluding mitochondrial volume) was not significantly different in epileptic rats $\left(3830 \pm 130\right.$ per $\left.\mu \mathrm{m}^{3}\right)$ and controls $\left(3380 \pm 250\right.$ per $\mu \mathrm{m}^{3}, p=0.15$, power $\left.=0.30\right)($ Fig. $8 J)$. These findings suggested that epileptic rats were not deficient in synaptic vesicles, which were proportionally more numerous in their enlarged boutons.

$\leftarrow$

(Figure legend continued.) Electron micrographs correspond to the sections indicated by the horizontal arrow in $\boldsymbol{C}$ and $\boldsymbol{F}$, respectively. $\boldsymbol{D}, \boldsymbol{H}$, Vertical arrows represent docked vesicles. Filled arrowheads represent borders of active zones on the postsynaptic side. Open arrowheads represent interface areas on the postsynaptic side. $I-M$, Measured parameters of boutons and mitochondria in control (cont) and epileptic rats (epi). Each marker represents the average of 10 boutons in one animal. Filled circles represent naive controls. Horizontal lines indicate group averages. ${ }^{*} p<0.05$. For details of statistical analysis, see text.
Proximity of synaptic vesicles to active zones can affect synaptic release probability (Gracheva et al., 2006; Marra et al., 2012; Park et al., 2012), so BC $\rightarrow \mathrm{GC}$ boutons were hypothesized to contain fewer synaptic vesicles close to active zones in epileptic rats. Distances between all vesicles and active zones were measured and sorted into bins of $50 \mathrm{~nm}$ increments. Contrary to the hypothesis, results revealed more vesicles closer to active zones in epileptic rats compared with controls (Fig. $8 \mathrm{~K}$ ). Average values of epileptic rats were greater than those of controls at all increments from the active zone. Differences were significant at all distances $(p<0.05$, repeated-measures ANOVA, power $=1.0)$, except the first bin $0-50 \mathrm{~nm}$ from the active zone.

Evidence from at least some excitatory hippocampal synapses indicates that docked vesicles are likely to be the morphological correlates of the readily releasable pool (Schikorski and Stevens, 
A

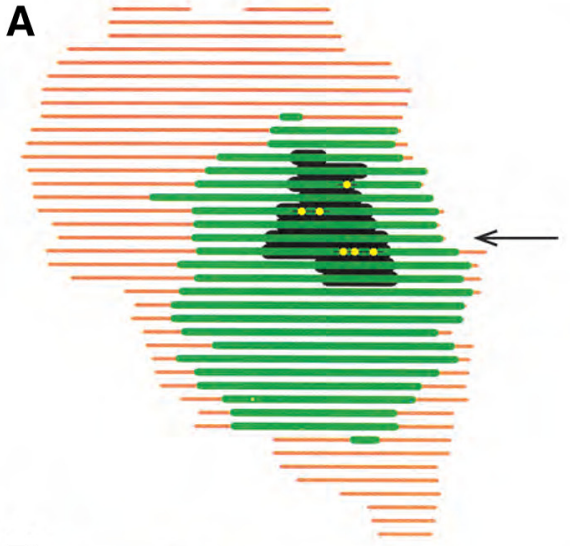

B
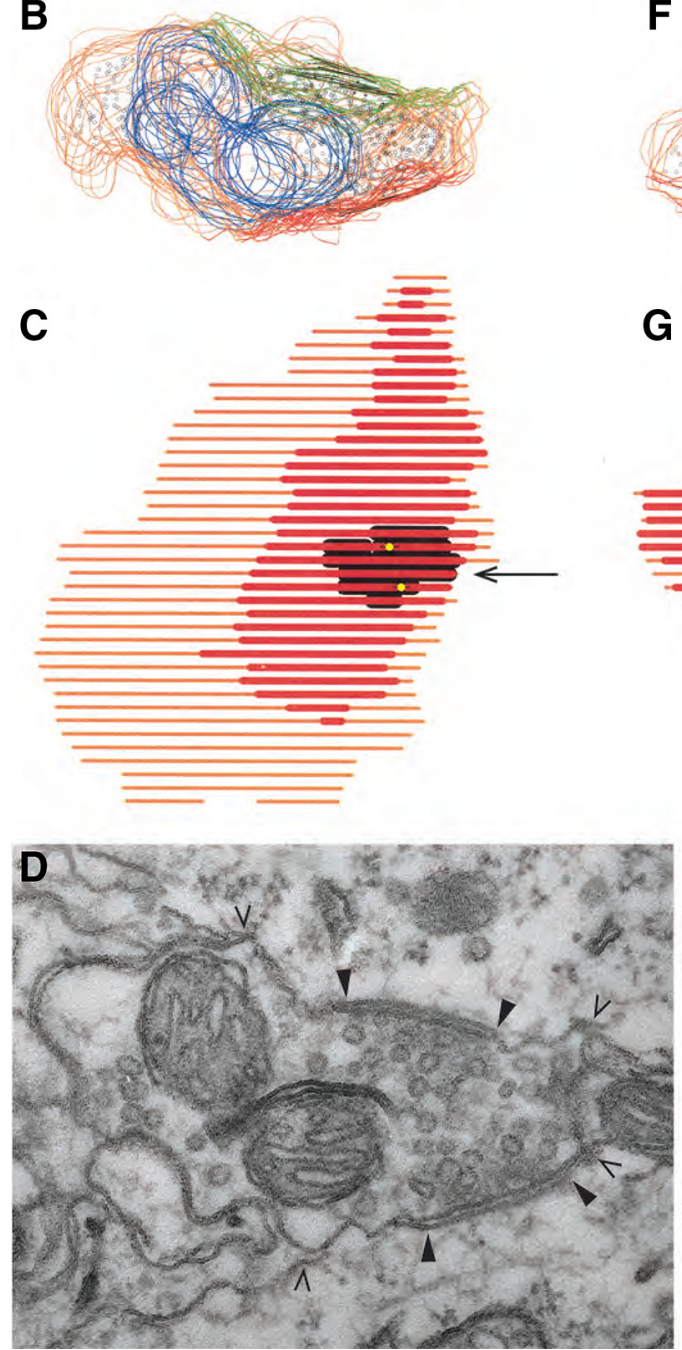

E
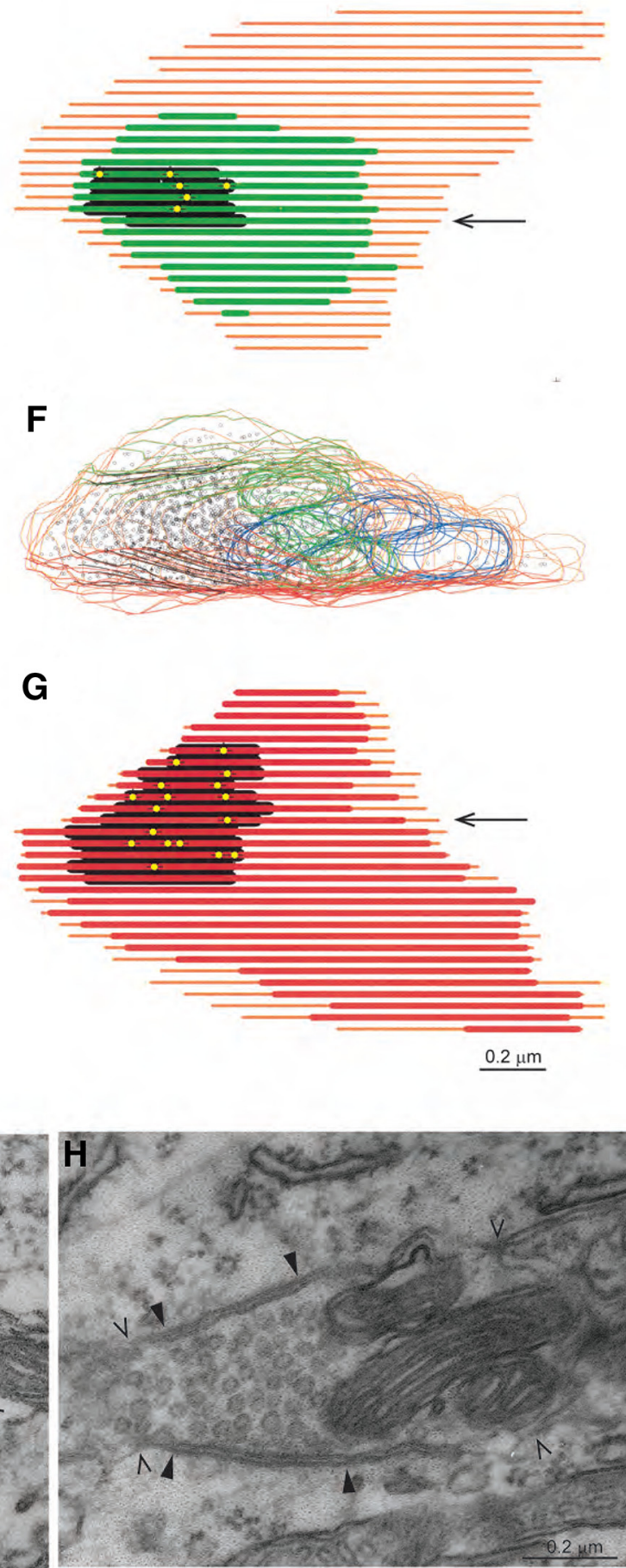

Figure 7. Surface views of double axosomatic synapses made with two different granule cells in control $(\boldsymbol{A}-\boldsymbol{D})$ and epileptic pilocarpine-treated rats $(\boldsymbol{E}-\boldsymbol{H})$. Contours of synaptic boutons (orange), interface areas of presynaptic and postsynaptic membrane apposition (red and green), and active zones (black) are indicated. Yellow circles represent docked vesicles. $\boldsymbol{B}, \boldsymbol{F}$, Side views. Blue and green represent mitochondria (different colors represent different mitochondria). Black circles represent clear vesicles. $\boldsymbol{D}, \boldsymbol{H}$, Electron micrographs of corresponding sections in reconstructions indicated by horizontal arrows in $\boldsymbol{A}, \boldsymbol{C}, \boldsymbol{E}$, and $\boldsymbol{G}$. Filled arrowheads represent borders of active zones on the postsynaptic side. Open arrowheads represent interface areas on the postsynaptic side.

2001; Watanabe et al., 2013). Because results of previous paired recordings suggested that readily releasable pools are smaller at $\mathrm{BC} \rightarrow \mathrm{GC}$ synapses in epileptic rats, it was hypothesized that those synapses would contain fewer docked vesicles. Docked vesicles were identified by their contact with an active zone (Figs. $2 F$, $5 D, H, 6 E, J)$. The number of docked vesicles per bouton was $2.5 \times$ higher in epileptic rats $(23.8 \pm 2.9)$ compared with controls
$(9.7 \pm 1.2, p=0.001, t$ test, power $=0.98)($ Fig. $9 A)$. The number of docked vesicles per interface was $2.4 \times$ higher in epileptic rats $(20.3 \pm 2.4)$ compared with controls $(8.4 \pm 0.9, p<0.001, t$ test, power $=0.99)$ (Fig. $9 B$ ). Previous studies found an average of 7-10 docked vesicles per active zone at excitatory synapses in the hippocampus (Schikorski and Stevens, 1997; Siksou et al., 2007) and cerebellum (Xu-Friedman et al., 2001). Similar results were 
found at $\mathrm{BC} \rightarrow \mathrm{GC}$ synapses in the present study. The number of docked vesicles per active zone was $1.9 \times$ higher in epileptic rats $(11.9 \pm 1.6)$ compared with controls $(6.4 \pm 0.8, p=0.013, t$ test, power $=0.78)$ (Fig. 9C). However, there was no significant difference in the number of docked vesicles per active zone area $(107 \pm 9$ per $\mu \mathrm{m}^{2}$ and $88 \pm 7$ per $\mu \mathrm{m}^{2}, p=0.14, t$ test, power $=0.31)$ in epileptic and controls rats, respectively (Fig. 9D) or in the proportion of total vesicles in the bouton that were docked $(1.22 \pm 0.11 \%$ and $1.50 \pm$ $0.26 \%$, respectively, $p=0.37$, $t$ test, power $=0.14)($ Fig. $9 E)$. Previous studies also found that $1 \%-2 \%$ of vesicles are docked in a variety of different types of synapses (for review, see Rizzoli and Betz, 2005). These findings revealed that, contrary to the hypothesis, epileptic rats were not deficient in docked vesicles at $\mathrm{BC} \rightarrow \mathrm{GC}$ synapses. Instead, they had proportionally more docked vesicles for their larger active zone areas.

\section{Discussion}

The principal findings of the present study are that, in epileptic pilocarpine-treated rats compared with controls, $\mathrm{BC} \rightarrow \mathrm{GC}$ synaptic boutons are larger and the axosomatic synapses they make have more and larger active zones and contain more vesicles, including more docked vesicles. These findings suggest that previously reported impaired transmission at $\mathrm{BC} \rightarrow \mathrm{GC}$ synapses in animal models of temporal lobe epilepsy is not attributable to smaller boutons or fewer docked vesicles.

\section{$\mathrm{BC} \rightarrow \mathrm{GC}$ boutons and synapses compared with others}

Ultrastructural features of boutons and symmetric axosomatic synapses in the granule cell layer of the present study were similar to those reported previously in other regions of the mammalian CNS. Those features included pleomorphic vesicles (Uchizono, 1965), active zones consisting of small discrete patches within a larger interface area (Peters et al., 1990), similar bouton volumes and active zone areas (Ledoux et al., 2005), and similar numbers of active zones per bouton (Biró et al., 2006). Like most previous reports, the present study used aldehyde fixation to preserve tissue, which can affect bouton volume and packing density of synaptic vesicles (Rostaing et al., 2006). However, control and experimental groups were treated identically, so comparisons between groups are likely to be valid.

Boutons and synapses evaluated in the present study resembled those reported previously in the granule cell layer that express glutamic acid decarboxylase and therefore are likely to

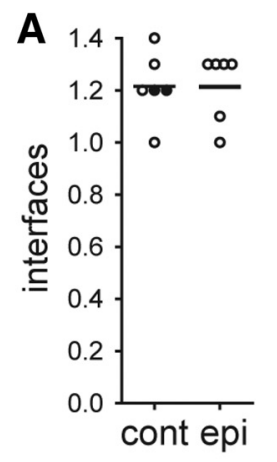

B
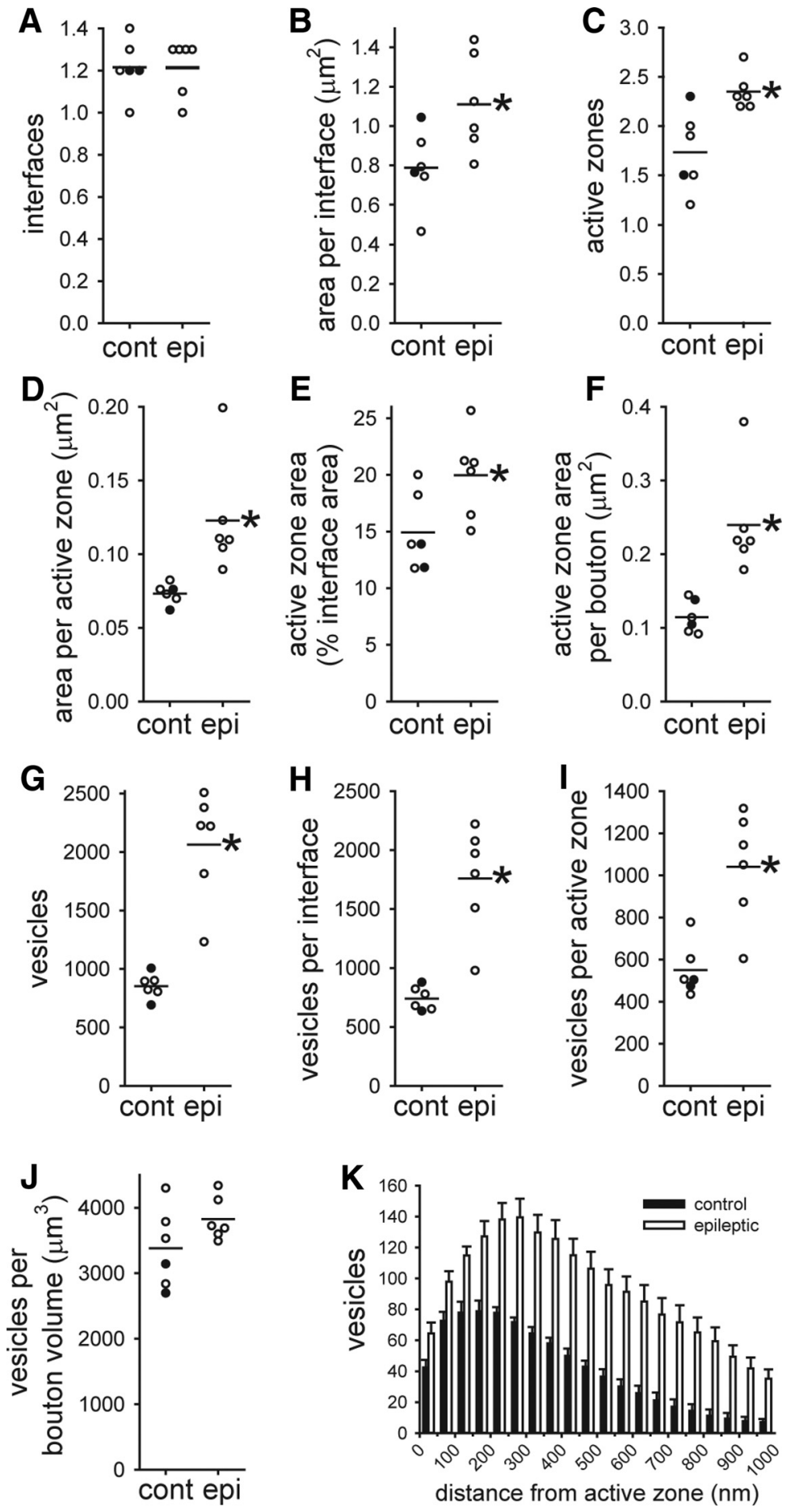

Figure 8. Interface $(\boldsymbol{A}, \boldsymbol{B})$, active zone $(\boldsymbol{C}-\boldsymbol{F})$, and vesicle parameters $(\boldsymbol{G}-\boldsymbol{J})$ at $\mathrm{BC} \rightarrow \mathrm{GC}$ synapses in control (cont) and epileptic pilocarpine-treated rats (epi). Each marker represents the average of 10 boutons in one animal. Filled circles represent naive controls. Horizontal lines indicate group averages. ${ }^{*} p<0.05$. For details of statistical analysis, see text. $\boldsymbol{K}$, Number of vesicles at 50 $\mathrm{nm}$ increments from an active zone. If a bouton contained multiple active zones, results were averaged. Values indicate mean \pm SEM of control and epileptic pilocarpine-treated groups. Differences in every bin, except the first, were significant ( $p<0.05$, repeated measures two-way ANOVA). synthesize GABA (Ribak et al., 1978; Kosaka et al., 1984). Dentate basket cells, which preferentially target granule cell somata (Struble et al., 1978; Ribak and Seress, 1983; Han et al., 1993; Lübke et al., 1998), were the most likely parent cell type of the 

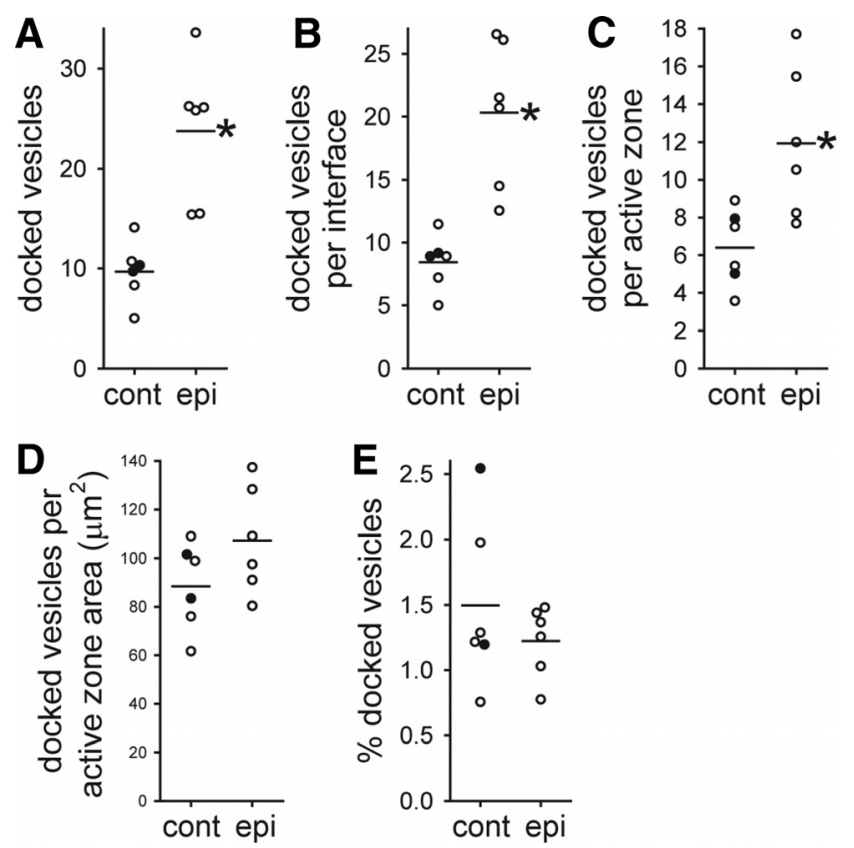

Figure 9. Docked vesicle parameters at $\mathrm{BC} \rightarrow \mathrm{GC}$ synapses in control (cont) and epileptic pilocarpine-treated rats (epi). Each marker represents the average of 10 boutons in one animal. Filled circles represent naive controls. Horizontal lines indicate group averages. ${ }^{*} p<0.05$. For details of statistical analysis, see text.

boutons evaluated in the present study, but the possibility that some boutons belonged to other types of interneurons cannot be excluded. Many, but not all, basket cells in the dentate gyrus express parvalbumin (Kosaka et al., 1987; Ribak et al., 1990), so many of the boutons evaluated were likely to be parvalbuminpositive. In the dentate gyrus, cholecystokinin-expressing interneurons target the inner molecular layer (Hefft and Jonas, 2005), not the principal cell layer as they do in CA1 (Nunzi et al., 1985), so boutons evaluated in the present study were unlikely to be cholecystokinin-positive.

The present study revealed ultrastructural changes at $\mathrm{BC} \rightarrow \mathrm{GC}$ synapses different from those reported for $\mathrm{BC} \rightarrow \mathrm{CA} 1$ pyramidal cell synapses in epileptic pilocarpine- and kainatetreated rats (Hirsch et al., 1999). In CA1, the frequency and amplitude of miniature IPSCs in pyramidal cells are reduced, but the number and size of GABAergic axosomatic boutons and number of docked vesicles are normal. However, the density of synaptic vesicles is reduced, especially $100-300 \mathrm{~nm}$ from active zones. In contrast, $\mathrm{BC} \rightarrow \mathrm{GC}$ boutons and synapses were larger and contained more vesicles, including more docked vesicles in epileptic pilocarpine-treated rats. These findings suggest that mechanisms underlying impaired GABAergic synaptic transmission can be regionally specific.

There was a positive correlation between the total number of vesicles and number of docked vesicles per bouton at $\mathrm{BC} \rightarrow \mathrm{GC}$ synapses, which is consistent with a mass action model of vesicle docking (Li and Schwarz, 1999; Gitler et al., 2004). In addition, previous studies found scaling relationships between the size of synaptic boutons and other ultrastructural features at excitatory (Harris and Stevens, 1989; Schikorski and Stevens, 1997) and inhibitory hippocampal synapses (Ledoux and Woolley, 2005; Eyre et al., 2007). Results of the present study were consistent and revealed that $\mathrm{BC} \rightarrow \mathrm{GC}$ boutons and synapses in epileptic rats were scaled up compared with controls. These findings suggest that there might be homeostatic mechanisms attempting to increase BC-mediated inhibition in epileptic animals. However, despite hypertrophied boutons and synapses, release probability is reduced at BC $\rightarrow$ GC synapses (Zhang and Buckmaster, 2009).

\section{Larger boutons and active zones are consistent with larger quantal amplitude}

A major finding of the present study was larger $\mathrm{BC} \rightarrow \mathrm{GC}$ boutons and synapses in epileptic pilocarpine-treated rats. Periods of high activity cause GABAergic synapses to enlarge in cultured hippocampal neurons (Rannals and Kapur, 2011). Larger boutons and larger active zone areas in the present study are consistent with larger amplitude miniature IPSCs in granule cells (Kobayashi and Buckmaster, 2003; Sun et al., 2007) and larger quantal size at $\mathrm{BC} \rightarrow \mathrm{GC}$ synapses in epileptic rats compared with controls (Zhang and Buckmaster, 2009). Similarly, kindling increases miniature IPSC amplitude in granule cells (Otis et al., 1994), increases the size of GABAergic boutons and synapses with granule cells, and increases the number of $\mathrm{GABA}_{\mathrm{A}}$ receptors per $\mathrm{BC} \rightarrow \mathrm{GC}$ synapse (Nusser et al., 1998). Thus, ultrastructural changes appear to underlie increased quantal amplitude at $\mathrm{BC} \rightarrow \mathrm{GC}$ synapses in temporal lobe epilepsy, but that is only part of synaptic efficacy. Release probability is another critical aspect.

\section{Possible mechanisms of impaired release at BC $\rightarrow$ GC synapses}

The motivation of the present study was to identify mechanisms of impaired GABA release at $\mathrm{BC} \rightarrow \mathrm{GC}$ synapses in temporal lobe epilepsy. The study tested and rejected the hypothesis that small, atrophic synaptic boutons with deficient docked vesicles were responsible. Consequently, it seems important to discuss alternative possible mechanisms. One of those is fewer synapses per $\mathrm{BC} \rightarrow \mathrm{GC}$ pair, which could reduce net release probability. In controls, basket cells make 3-7 release sites per granule cell (Kraushaar and Jonas, 2000). To our knowledge, that parameter has not been measured in temporal lobe epilepsy, but available evidence suggests that fewer release sites are unlikely. Patients with temporal lobe epilepsy (Wittner et al., 2001) and pilocarpine-treated rats (Thind et al., 2010) do not display significant loss of axosomatic inhibitory synapses in the granule cell layer. The probability of finding synaptically coupled $\mathrm{BC} \rightarrow \mathrm{GC}$ pairs is not significantly reduced in epileptic pilocarpine-treated rats (Zhang and Buckmaster, 2009). And the present study found identical average numbers of $\mathrm{BC} \rightarrow \mathrm{GC}$ synapses per bouton in control and epileptic rats. Together, these findings suggest that impaired transmission at $\mathrm{BC} \rightarrow \mathrm{GC}$ synapses is not attributable to fewer synapses, smaller boutons, or fewer docked vesicles.

Another possibility is impaired vesicle priming at $\mathrm{BC} \rightarrow \mathrm{GC}$ synapses in temporal lobe epilepsy. After docking, synaptic vesicles must undergo priming before they are ready for $\mathrm{Ca}^{2+}$. triggered fusion (for review, see Südhof, 2013). At many glutamatergic synapses, Munc13 proteins are necessary for vesicle priming (Augustin et al., 1999). Munc13 protein function can be modulated by protein interactions (Betz et al., 2001) and second messengers (Betz et al., 1998), suggesting possibilities for regulating synaptic release probability independently of the number of morphologically docked vesicles. Presumably GABAergic synapses include molecules of comparable function to those of Munc13s, and at least one regulator of vesicle priming at GABAergic synapses has been identified (Kaeser et al., 2009). Therefore, downregulated vesicle priming, possibly via a Munc13-like protein, is another possible mechanism for failure of transmission at $\mathrm{BC} \rightarrow \mathrm{GC}$ synapses in temporal lobe epilepsy. 
Finally, findings of the present study reveal hypertrophied synaptic boutons and more docked vesicles at synapses previously shown to have reduced release probability, which seems to contradict other published results that release probability is higher at synapses made by larger boutons containing more vesicles, especially more docked vesicles (Murthy et al., 1997, 2001; Mackenzie et al., 1999; Schikorski and Stevens, 2001; Branco et al., 2010; Matz et al., 2010; Holderith et al., 2012). Results from $\mathrm{BC} \rightarrow \mathrm{GC}$ synapses in epileptic pilocarpine-treated rats seem to contradict that hypothesis because release probability is reduced (Zhang and Buckmaster, 2009), but boutons and active zones were large and docked vesicles were abundant. There are several possible reasons for the apparent contradiction. First, most of the evidence for correlations between ultrastructural characteristics and release probability were derived from glutamatergic synapses. However, glutamatergic and GABAergic synapses use different vesicle exocytosis mechanisms (Augustin et al., 1999; Schoch et al., 2002; Gitler et al., 2004; Verderio et al., 2004; Bragina et al., 2007; Kerr et al., 2008; Gibson et al., 2009; Kaeser et al., 2009; Benagiano et al., 2011). Therefore, the relationship between synaptic efficacy and bouton ultrastructure, active zone size, and number of docked vesicles might be different in GABAergic synapses. Second, synaptic release probability can be dissociated from ultrastructural features. This occurs naturally; for example, cerebellar climbing fibers and parallel fibers share similar ultrastructural features but display different release probabilities (Xu-Friedman et al., 2001). Release probability can also be experimentally manipulated without affecting docked vesicle numbers (Hess et al., 1993; Augustin et al., 1999; Schoch et al., 2002; Sørensen et al., 2003; Kaeser et al., 2009). Therefore, docked vesicles might not always represent the readily releasable pool.

Results of the present study suggest that previously reported impaired transmission at $\mathrm{BC} \rightarrow \mathrm{GC}$ synapses is not attributable to smaller boutons or fewer docked vesicles. Instead, later steps in exocytosis might be deficient in epileptic animals. Tight spatial coupling between a small number of $\mathrm{Ca}^{2+}$ channels (Bucurenciu et al., 2010) and $\mathrm{Ca}^{2+}$ sensors in the active zone facilitates normally reliable synaptic transmission at $\mathrm{BC} \rightarrow \mathrm{GC}$ synapses (Bucurenciu et al., 2008). Therefore, one possibility is that in temporal lobe epilepsy $\mathrm{Ca}^{2+}$ entry or $\mathrm{Ca}^{2+}$ coupling with exocytosis is impaired at $\mathrm{BC} \rightarrow \mathrm{GC}$ synapses. In a neocortical model of post-traumatic epilepsy, inhibitory synaptic transmission is more likely to fail (Faria and Prince, 2010; Ma and Prince, 2012), which correlates with changes in calcium channels (Faria et al., 2012).

\section{References}

Augustin I, Rosenmund C, Südhof TC, Brose N (1999) Munc13-1 is essential for fusion competence of glutamatergic synaptic vesicles. Nature 400: 457-461. CrossRef Medline

Benagiano V, Lorusso L, Flace P, Girolamo F, Rizzi A, Bosco L, Cagiano R, Nico B, Ribatti D, Ambrosi G (2011) VAMP-2, SNAP-25A/B and syntaxin-1 in glutamatergic and GABAergic synapses of the rat cerebellar cortex. BMC Neurosci 12:118. CrossRef Medline

Betz A, Ashery U, Rickmann M, Augustin I, Neher E, Südhof TC, Rettig J, Brose N (1998) Munc13-1 is a presynaptic phorbol ester receptor that enhances neurotransmitter release. Neuron 21:123-136. CrossRef Medline

Betz A, Thakur P, Junge HJ, Ashery U, Rhee JS, Scheuss V, Rosenmund C, Rettig J, Brose N (2001) Functional interaction of the active zone proteins Munc13-1 and RIM1 in synaptic vesicle priming. Neuron 30: 183-196. CrossRef Medline

Biró AA, Holderith NB, Nusser Z (2006) Release probability-dependent scaling of the postsynaptic responses at single hippocampal GABAergic synapses. J Neurosci 26:12487-12496. CrossRef Medline

Bragina L, Candiracci C, Barbaresi P, Giovedì S, Benfenati F, Conti F (2007)
Heterogeneity of glutamatergic and GABAergic release machinery in cerebral cortex. Neuroscience 146:1829-1840. CrossRef Medline

Branco T, Marra V, Staras K (2010) Examining size-strength relationships at hippocampal synapses using an ultrastructural measurement of synaptic release probability. J Struct Biol 172:203-210. CrossRef Medline

Buckmaster PS, Dudek FE (1997) Neuron loss, granule cell axon reorganization, and functional changes in the dentate gyrus of epileptic kainatetreated rats. J Comp Neurol 385:385-404. CrossRef Medline

Bucurenciu I, Kulik A, Schwaller B, Frotscher M, Jonas P (2008) Nanodomain coupling between $\mathrm{Ca}^{2+}$ channels and $\mathrm{Ca}^{2+}$ sensors promotes fast and efficient transmitter release at a cortical GABAergic synapse. Neuron 57:536-545. CrossRef Medline

Bucurenciu I, Bischofberger J, Jonas P (2010) A small number of open $\mathrm{Ca}^{2+}$ channels trigger transmitter release at a central GABAergic synapse. Nat Neurosci 13:19-21. CrossRef Medline

Cronin J, Obenaus A, Houser CR, Dudek FE (1992) Electrophysiology of dentate granule cells after kainate-induced synaptic reorganization of the mossy fibers. Brain Res 573:305-310. CrossRef Medline

Eyre MD, Freund TF, Gulyas AI (2007) Quantitative ultrastructural differences between local and medial septal GABAergic axon terminals in the rat hippocampus. Neuroscience 149:537-548. CrossRef Medline

Faria LC, Prince DA (2010) Presynaptic inhibitory terminals are functionally abnormal in a rat model of posttraumatic epilepsy. J Neurophysiol 104:280-290. CrossRef Medline

Faria LC, Parada I, Prince DA (2012) Interneuronal calcium channel abnormalities in posttraumatic epileptogenic neocortex. Neurobiol Dis 45: 821-828. CrossRef Medline

Gabriel S, Njunting M, Pomper JK, Merschhemke M, Sanabria ER, Eilers A, Kivi A, Zeller M, Meencke HJ, Cavalheiro EA, Heinemann U, Lehmann TN (2004) Stimulus and potassium-induced epileptiform activity in the human dentate gyrus from patients with and without hippocampal sclerosis. J Neurosci 24:10416-10430. CrossRef Medline

Gao J, Chi ZF, Liu XW, Shang PY, Wang R (2007) Mitochondrial dysfunction and ultrastructural damage in the hippocampus of pilocarpineinduced epileptic rat. Neurosci Lett 411:152-157. CrossRef Medline

Gibson JR, Huber KM, Südhof TC (2009) Neuroligin-2 deletion selectively decreases inhibitory synaptic transmission originating from fast-spiking but not from somatostatin-positive interneurons. J Neurosci 29:1388313897. CrossRef Medline

Gitler D, Takagishi Y, Feng J, Ren Y, Rodriguiz RM, Wetsel WC, Greengard P, Augustine GJ (2004) Different presynaptic roles of synapsins at excitatory and inhibitory synapses. J Neurosci 24:11368-11380. CrossRef Medline

Gracheva EO, Burdina AO, Holgado AM, Berthelot-Grosjean M, Ackley BD, Hadwiger G, Nonet ML, Weimer RM, Richmond JE (2006) Tomosyn inhibits synaptic vesicle priming in Caenorhabditis elegans. PLoS Biol 4:e261. CrossRef Medline

Gray EG (1959) Axo-somatic and axo-dendritic synapses of the cerebral cortex. J Anat (Lond) 93:420-433. Medline

Han ZS, Buhl EH, Lörinczi Z, Somogyi P (1993) A high degree of spatial selectivity in the axonal and dendritic domains of physiologically identified local-circuit neurons in the dentate gyrus of the rat hippocampus. Eur J Neurosci 5:395-410. CrossRef Medline

Harris KM, Stevens JK (1989) Dendritic spines of CA1 pyramidal cells in the rat hippocampus: serial electron microscopy with reference to their biophysical characteristics. J Neurosci 9:2982-2997. Medline

Harris KM, Sultan P (1995) Variation in the number, location and size of synaptic vesicles provides an anatomical basis for the nonuniform probability of release at hippocampal CA1 synapses. Neuropharmacology 34: 1387-1395. CrossRef Medline

Hefft S, Jonas P (2005) Asynchronous GABA release generates long-lasting inhibition at a hippocampal interneuron-principal neuron synapse. Nat Neurosci 8:1319-1328. CrossRef Medline

Hesdorffer DC, Logroscino G, Benn EK, Katri N, Cascino G, Hauser WA (2011) Estimating risk for developing epilepsy. Neurology 76: 23-27. CrossRef Medline

Hess SD, Doroshenko PA, Augustine GJ (1993) A functional role for GTPbinding proteins in synaptic vesicle cycling. Science 259:1169-1172. CrossRef Medline

Hirsch JC, Agassandian C, Merchán-Pérez A, Ben-Ari Y, DeFelipe J, Esclapez M, Bernard C (1999) Deficit of quantal release of GABA in experimental 
models of temporal lobe epilepsy. Nat Neurosci 2:499-500. CrossRef Medline

Holderith N, Lorincz A, Katona G, Rózsa B, Kulik A, Watanabe M, Nusser Z (2012) Release probability of hippocampal glutamatergic terminals scales with the size of the active zone. Nat Neurosci 15:988-997. CrossRef Medline

Kaeser PS, Deng L, Chávez AE, Liu X, Castillo PE, Südhof TC (2009) ELKS2 $\alpha / C A S T$ deletion selectively increases neurotransmitter release at inhibitory synapses. Neuron 64:227-239. CrossRef Medline

Kerr AM, Reisinger E, Jonas P (2008) Differential dependence of phasic transmitter release on synaptotagmin 1 at GABAergic and glutamatergic hippocampal synapses. Proc Natl Acad Sci U S A 105:15581-15586. CrossRef Medline

Kobayashi M, Buckmaster PS (2003) Reduced inhibition of dentate granule cells in a model of temporal lobe epilepsy. J Neurosci 23:2440-2452. Medline

Kobayashi M, Wen X, Buckmaster PS (2003) Reduced inhibition and increased output of layer II neurons in the medial entorhinal cortex in a model of temporal lobe epilepsy. J Neurosci 23:8471-8479. Medline

Kosaka T, Hama K, Wu JY (1984) GABAergic synaptic boutons in the granule cell layer of rat dentate gyrus. Brain Res 293:353-359. CrossRef Medline

Kosaka T, Katsumaru H, Hama K, Wu JY, Heizmann CW (1987) GABAergic neurons containing the $\mathrm{Ca}^{2+}$-binding protein parvalbumin in the rat hippocampus and dentate gyrus. Brain Res 419:119-130. CrossRef Medline

Kraushaar U, Jonas P (2000) Efficacy and stability of quantal GABA release at a hippocampal interneuron-principal neuron synapse. J Neurosci 20: 5594-5607. Medline

Kumar SS, Buckmaster PS (2006) Hyperexcitability, interneurons, and loss of GABAergic synapses in entorhinal cortex in a model of temporal lobe epilepsy. J Neurosci 26:4613-4623. CrossRef Medline

Kunz WS, Kudin AP, Vielhaber S, Blümcke I, Zuschratter W, Schramm J, Beck H, Elger CE (2000) Mitochondrial complex I deficiency in the epileptic focus of patients with temporal lobe epilepsy. Ann Neurol 48: 766-773. CrossRef Medline

Kwan P, Brodie MJ (2000) Early identification of refractory epilepsy. N Engl J Med 342:314-319. CrossRef Medline

Ledoux VA, Woolley CS (2005) Evidence that disinhibition is associated with a decrease in number of vesicles available for release at inhibitory synapses. J Neurosci 25:971-976. CrossRef Medline

Li J, Schwarz TL (1999) Genetic evidence for an equilibrium between docked and undocked vesicles. Philos Trans R Soc Lond B Biol Sci 354: 299-306. CrossRef Medline

Lübke J, Frotscher M, Spruston N (1998) Specialized electrophysiological properties of anatomically identified neurons in the hilar region of the rat fascia dentate. J Neurophysiol 79:1518-1534. Medline

Ma Y, Prince DA (2012) Functional alterations in GABAergic fast-spiking interneurons in chronically injured epileptogenic neocortex. Neurobiol Dis 47:102-113. CrossRef Medline

Mackenzi PJ, Kenner GS, Prange O, Shayan H, Umemiya M, Murphy TH (1999) Ultrastructural correlates of quantal synaptic function at single CNS synapses. J Neurosci 19:RC13. Medline

Marra V, Burden JJ, Thorpe JR, Smith IT, Smith SL, Häusser M, Branco T, Staras K (2012) A preferentially segregated recycling vesicle pool of limited size supports neurotransmission in native central synapses. Neuron 76:579-589. CrossRef Medline

Matz J, Gilyan A, Kolar A, McCarvill T, Krueger SR (2010) Rapid structural alterations of the active zone lead to sustained changes in neurotransmitter release. Proc Natl Acad Sci U S A 107:8836-8841. CrossRef Medline

Murthy VN, Sejnowski TJ, Stevens CF (1997) Heterogeneous release properties of visualized individual hippocampal synapses. Neuron 18: 599-612. CrossRef Medline

Murthy VN, Schikorski T, Stevens CF, Zhu Y (2001) Inactivity produces increases in neurotransmitter release and synapse size. Neuron 32: 673-682. CrossRef Medline

Nadler JV, Perry BW, Cotman CW (1978) Intraventricular kainic acid preferentially destroys hippocampal pyramidal cells. Nature 271:676-677. CrossRef Medline

Nunzi MG, Gorio A, Milan F, Freund TF, Somogyi P, Smith AD (1985) Cholecystokinin-immunoreactive cells form symmetrical synaptic contacts with pyramidal and nonpyramidal neurons in the hippocampus. J Comp Neurol 237:485-505. CrossRef Medline
Nusser Z, Hájos N, Somogyi P, Mody I (1998) Increased number of synaptic $\mathrm{GABA}_{\mathrm{A}}$ receptors underlies potentiation at hippocampal inhibitory synapses. Nature 395:172-177. CrossRef Medline

Otis TS, De Koninck Y, Mody I (1994) Lasting potentiation of inhibition is associated with an increased number of gamma-aminobutyric acid type A receptors activated during miniature inhibitory postsynaptic currents. Proc Natl Acad Sci U S A 91:7698-7702. CrossRef Medline

Park H, Li Y, Tsien RW (2012) Influence of synaptic vesicle position on release probability and exocytotic fusion mode. Science 335:1362-1366. CrossRef Medline

Paxinos G, Watson C (1998) The rat brain in stereotaxic coordinates, Ed 4. San Diego: Academic.

Peters A, Harriman KM (1990) Different kinds of axon terminals forming symmetric synapses with the cell bodies and initial axon segments of layer II/III pyramidal cells: I. Morphometric analysis. J Neurocytol 19: 154-174. CrossRef Medline

Peters A, Sethares C, Harriman KM (1990) Different kinds of axon terminals forming symmetric synapses with the cell bodies and initial axon segments of layer II/III pyramidal cells: II. Synaptic junctions. J Neurocytol 19:584-600. CrossRef Medline

Picot MC, Baldy-Moulinier M, Daurès JP, Dujols P, Crespel A (2008) The prevalence of epilepsy and pharmacoresistant epilepsy in adults: a population-based study in a western European country. Epilepsia 49: 1230-1238. CrossRef Medline

Pierce JP, Lewin GR (1994) An ultrastructural size principle. Neuroscience 58:441-446. CrossRef Medline

Quesney LF (1986) Clinical and EEG features of complex partial seizures of temporal lobe origin. Epilepsia 27 [Suppl 2]:S27-S45.

Racine RJ (1972) Modification of seizure activity by electrical stimulation: II. Motor seizure. Electroencephalogr Clin Neurophysiol 32:281-294. CrossRef Medline

Rannals MD, Kapur J (2011) Homeostatic strengthening of inhibitory synapses is mediated by the accumulation of GABAA receptors. J Neurosci 31:17701-17712. CrossRef Medline

Ribak CE, Seress L (1983) Five types of basket cell in the hippocampal dentate gyrus: a combined Golgi and electron microscopic study. J Neurocytol 12:577-597. CrossRef Medline

Ribak CE, Vaughn JE, Saito K (1978) Immunocytochemical localization of glutamic acid decarboxylase in neuronal somata following colchicine inhibition of axonal transport. Brain Res 140:315-332. CrossRef Medline

Ribak CE, Nitsch R, Seress L (1990) Proportion of parvalbumin-positive basket cells in the GABAergic innervation of pyramidal and granule cells of the rat hippocampal formation. J Comp Neurol 300:449-461. CrossRef Medline

Rizzoli SO, Betz WJ (2005) Synaptic vesicle pools. Nat Rev 6:57-69. CrossRef Medline

Rostaing P, Real E, Siksou L, Lechaire JP, Boudier T, Boeckers TM, Gertler F, Gundelfinger ED, Triller A, Marty S (2006) Analysis of synaptic ultrastructure without fixative using high-pressure freezing and tomography. Eur J Neurosci 24:3463-3474. CrossRef Medline

Schikorski T, Stevens CF (1997) Quantitative ultrastructural analysis of hippocampal excitatory synapses. J Neurosci 17:5858-5867. Medline

Schikorski T, Stevens CF (2001) Morphological correlates of functionally defined synaptic vesicle populations. Nat Neurosci 4:391-395. CrossRef Medline

Schoch S, Castillo PE, Jo T, Mukherjee K, Geppert M, Wang Y, Schmitz F, Malenka RC, Südhof TC (2002) RIM1 $\alpha$ forms a protein scaffold for regulating neurotransmitter release at the active zone. Nature 415: 321-326. CrossRef Medline

Shao LR, Dudek FE (2005) Changes in mIPSCs and sIPSCs after kainate treatment: evidence for loss of inhibitory input to dentate granule cells and possible compensatory responses. J Neurophysiol 94:952-960. CrossRef Medline

Siksou L, Rostaing P, Lechaire JP, Boudier T, Ohtsuka T, Fejtová A, Kao HT, Greengard P, Gundelfinger ED, Triller A, Marty S (2007) Threedimensional architecture of presynaptic terminal cytomatrix. J Neurosci 27:6868-6877. CrossRef Medline

Soltesz I, Smetters DK, Mody I (1995) Tonic inhibition originates from synapses close to the soma. Neuron 14:1273-1283. CrossRef Medline

Sørensen JB, Nagy G, Varoqueaux F, Nehring RB, Brose N, Wilson MC, Neher E (2003) Differential control of the releasable vesicle pools by SNAP-25 splice variants and SNAP-23. Cell 114:75-86. CrossRef Medline 
Spanedda F, Cendes F, Gotman J (1997) Relations between EEG seizure morphology, interhemispheric spread, and mesial temporal atrophy in bitemporal epilepsy. Epilepsia 38:1300-1314. CrossRef Medline

Spencer SS, Williamson PD, Spencer DD, Mattson RH (1987) Human hippocampal seizure spread studied by depth and subdural recording: the hippocampal commissure. Epilepsia 28:479-489. CrossRef Medline

Sperling MR, O'Connor MJ (1989) Comparison of depth and subdural electrodes in recording temporal lobe seizures. Neurology 39:1497-1504. CrossRef Medline

Struble RG, Desmond NL, Levy WB (1978) Anatomical evidence for interlamellar inhibition in the fascia dentate. Brain Res 152:580-585. CrossRef Medline

Südhof TC (2013) Neurotransmitter release: the last millisecond in the life of a synaptic vesicle. Neuron 80:675-690. CrossRef Medline

Sun C, Mtchedlishvili Z, Bertram EH, Erisir A, Kapur J (2007) Selective loss of dentate hilar interneurons contributes to reduced synaptic inhibition of granule cells in an electrical stimulation-based model of temporal lobe epilepsy. J Comp Neurol 500:876-893. CrossRef Medline

Téllez-Zenteno JF, Hernández-Ronquillo L (2012) A review of the epidemiology of temporal lobe epilepsy. Epilepsy Res Treat 2012:630853. CrossRef Medline

Thind KK, Yamawaki R, Phanwar I, Zhang G, Wen X, Buckmaster PS (2010) Initial loss but later excess of GABAergic synapses with dentate granule cells in a rat model of temporal lobe epilepsy. J Comp Neurol 518: 647-667. CrossRef Medline

Toyoda I, Bower MR, Leyva F, Buckmaster PS (2013) Early activation of ventral hippocampus and subiculum during spontaneous seizures in a rat model of temporal lobe epilepsy. J Neurosci 33:11100-11115. CrossRef Medline

Uchizono K (1965) Characteristics of excitatory and inhibitory synapses in the central nervous system of the cat. Nature 207:642-643. CrossRef Medline
Verderio C, Pozzi D, Pravettoni E, Inverardi F, Schenk U, Coco S, ProuxGillardeaux V, Galli T, Rossetto O, Frassoni C, Matteoli M (2004) SNAP-25 modulation of calcium dynamics underlies differences in GABAergic and glutamatergic responsiveness to depolarization. Neuron 41:599-610. CrossRef Medline

Verstreken P, Ly CV, Venken KJ, Koh TW, Zhou Y, Bellen HJ (2005) Synaptic mitochondria are critical for mobilization of reserve pool vesicles at Drosophila neuromuscular junctions. Neuron 47:365-378. CrossRef Medline

Watanabe S, Rost BR, Camacho-Pérez M, Davis MW, Söhl-Kielczynski B, Rosenmund C, Jorgensen EM (2013) Ultrafast endocytosis at mouse hippocampal synapses. Nature 504:242-247. CrossRef Medline

Williamson A, Spencer SS, Spencer DD (1995) Depth electrode studies and intracellular dentate granule cell recordings in temporal lobe epilepsy. Ann Neurol 38:778-787. CrossRef Medline

Williamson A, Patrylo PR, Spencer DD (1999) Decrease in inhibition in dentate granule cells from patients with temporal lobe epilepsy. Ann Neurol 45:92-99. CrossRef Medline

Wittner L, Maglóczky Z, Borhegyi Z, Halász P, Tóth S, Eross L, Szabó Z, Freund TF (2001) Preservation of perisomatic inhibitory input of granule cells in the epileptic human dentate gyrus. Neuroscience 108:587-600. CrossRef Medline

Xu-Friedman MA, Harris KM, Regehr WG (2001) Three-dimensional comparison of ultrastructural characteristics at depressing and facilitating synapses onto cerebellar Purkinje cells. J Neurosci 21:6666-6672. Medline

Zar JH (1984) Biostatistical analysis, p 174. Englewood Cliffs, NJ: Prentice-Hall.

Zhang W, Buckmaster PS (2009) Dysfunction of the dentate basket cell circuit in a rat model of temporal lobe epilepsy. J Neurosci 29:7846-7856. CrossRef Medline 